\title{
Syntheses, Characterization and Biological Activity of Novel Thiazoylazo Dye and Its Coordination Compounds
}

\author{
Temitayo 0. Aiyelabola \\ Department of Chemistry, Obafemi Awolowo University, Ile-Ife, Osun State, Nigeria \\ Email: taiyelabola@gmail.com
}

How to cite this paper: Aiyelabola, T.O. (2021) Syntheses, Characterization and Biological Activity of Novel Thiazoylazo Dye and Its Coordination Compounds. Advances in Biological Chemistry, 11, 179-205. https://doi.org/10.4236/abc.2021.115013

Received: August 2, 2021

Accepted: September 24, 2021

Published: September 27, 2021

Copyright $\odot 2021$ by author(s) and Scientific Research Publishing Inc. This work is licensed under the Creative Commons Attribution International License (CC BY 4.0).

http://creativecommons.org/licenses/by/4.0/

\begin{abstract}
The present work describes the synthesis of a novel heterocyclic azo dye by general diazonization of 2-amino-4,5-dimethylthiazole followed by the diazocoupling of the resulting diazonium ion with 5-methyl-2-(propan-2-yl)phenol to obtain ligand $\mathrm{L}$. This was characterized using Fourier-transformed infrared and electronic spectrophotometry. Ligand $\mathbf{L}$ was further coordinated with five metal ions, M:L, 1:2 [M = Cu(II), $\mathrm{Mn}(\mathrm{II}), \mathrm{Zn}(\mathrm{II}), \mathrm{Ni}(\mathrm{II})$ and $\mathrm{Co}(\mathrm{II})]$. The coordination compounds obtained were characterized by electronic, IR spectrophotometry, magnetic susceptibility and percentage metal analyses. The results obtained suggested that a thiazoylazo dye was obtained as ligand L. It was proposed that two molecules of the solvent coordinated to the metal ion in addition with the ligands to give an octahedral geometry for copper(II), manganese(II) and nickel(II) complexes. On the other hand, square planar geometry was suggested for zinc(II) and cobalt(II) complexes. The anti-inflammatory activity of the ligand and coordination compounds was evaluated using four in vitro-based assays viz: xanthine oxidase and lipoxygenase inhibition assay, membrane stability and protein denaturation assay. The synthesized compounds generally exhibited good anti-inflammatory activity in all the assays carried out. However, the reference standards, in this instance, were more effective in the case of xanthine oxidase, lipoxygenase and protein denaturation inhibitory assays. For the membrane stability study, the coordination compounds and ligand L elicited more potent anti-inflammatory activity than the standard drug.
\end{abstract}

\section{Keywords}

Coordination Compounds, 2-Amino-4,5-Dimethylthiazole, 5-Methyl-2-(Propan-2-yl)phenol, Anti-Inflammation, Thiazolylazo Dye 


\section{Introduction}

The actions of many drugs currently in the market involve enzyme inhibition, as such enzymes have been prime targets for drug design [1] [2] [3] [4] [5]. This is because altering their activity has immediate and defined effects. Currently, 47\% of all drugs in the market are enzyme inhibitors [1]. This includes tofacitinib, a JAK 3 inhibitor, approved for the treatment of rheumatoid arthritis in 2012 [5]. Aspirin, which inhibits cyclooxygenase, used for inflammation, pain and fever, is also an example. Another one is penicillin, an irreversible suicidal inhibitor of transpeptidase, used to combat bacterial infection [5]. In more recent times, metal complexes are increasingly being used to inhibit enzymes as well. This may arise from their unique properties that are appealing features for enzyme inhibition. These include the facile construction of 3D structures that can increase enzyme-binding selectivity and affinity, photophysical and photochemical properties that may be fine-tuned, to enhance enzyme inhibition [6]-[11]. A commercially available example is auranofin, a gold complex used as an antirheumatic agent.

One of the common conditions of our time that may induce, maintain or aggravate many diseases is chronic inflammation [12] [13] [14]. Inflammation is referred to as a complex biological response of vascular tissues to harmful stimuli [15] [16]. The response of the body to harmful stimuli is achieved by the progressive movement of plasma and leukocyte constituents from the blood into the injured tissues or locations [15] [17]. Other processes embedded in the response to harmful stimuli in addition to inflammation include angiogenesis and remodeling [8] [15] [18] [19]. These processes are self-limiting under normal healing conditions. However, if one or more of those processes are maintained further, injury is caused resulting in various diseases which may include chronic inflammatory conditions, such as rheumatoid arthritis [20] [21] [22].

Azo dyes are a class of organic compounds that are constantly receiving attention in research. This is due to their versatile applications in various fields such as textiles, paint and medicine as anti-bacterial, -cancer, and -inflammatory agents [23]-[28]. A class of heterocyclic azo dyes is the thiazolylazo dye. Thiazoles are an important class of heterocyclic compounds which are related with many types of biological properties, probably by virtue of the -N=C-S- group, these include insecticidal, herbicidal, anti-oxidant, -bacterial, -convulsant and -inflammatory [29] [30] [31] [32] [33]. Thiazoles are readily capable of crossing cellular membranes owing to their better liposolubility, attributed to the presence of a sulphur atom [32]. The thiazole ring is present in several potent pharmacologically active molecules such as sulfathiazole (an antimicrobial drug), ritonavir (an antiretroviral drug) and abafungin (an antifungal drug) [34]. More importantly, a thiazole derivative is widely used as a non-steroidal anti-inflammatory drug, meloxicam. It blocks cyclooxygenase, the enzyme responsible for converting arachidonic acid into prostaglandins which are mediators of inflammation [35].

Although there are a number of anti-inflammatory drugs currently in the market, however, they exhibit significant adverse effects. In this respect, coordi- 
nation chemistry may be deemed as a useful tool in curbing this [36] [37] [38] [39]. Earlier investigations have revealed that coordination of metal ions to biologically active agents may improve their efficiency and bioavailability and in some cases, reduce their well-recognized side effects [36] [37] [38] [39]. In light of the foregoing, our group was stimulated to explore the potential of a novel thiazoylazo dye derivative and its coordination compounds as lead compounds as a chemotherapeutic anti-inflammatory agent and with possibly fewer side effects. It was therefore considered to synthesize a novel thiazoylazo dye by diazo-coupling of the diazonium ion of 2-amino-4,5-dimethylthiazole (Figure 1) with 5-methyl-2-(propan-2-yl)phenol (Figure 2) to obtain ligand L (Figure 3). This was characterized using FTIR and electronic spectrophotometry. The ligand obtained was coordinated to five metal ions viz: copper(II), manganese(II), zinc(II), nickel(II) and cobalt(II) to give compounds 1-5. These were characterized using FTIR, electronic spectrophotometry, magnetic susceptibility measurement and percentage metal analyses. Ligand $\mathrm{L}$ and the coordination compounds obtained were studied for their enzymatic inhibitory and anti-inflammatory activities.

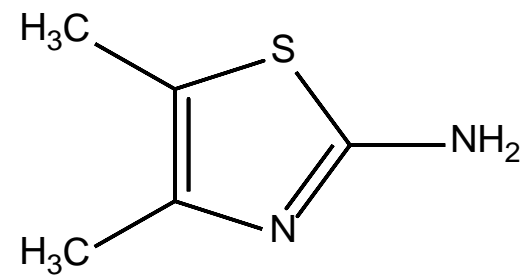

Figure 1. 2-amino-4,5-dimethylthiazole.<smiles>Cc1ccc(C(C)C)c(O)c1</smiles>

Figure 2. 5-methyl-2-(propan-2-yl)phenol.

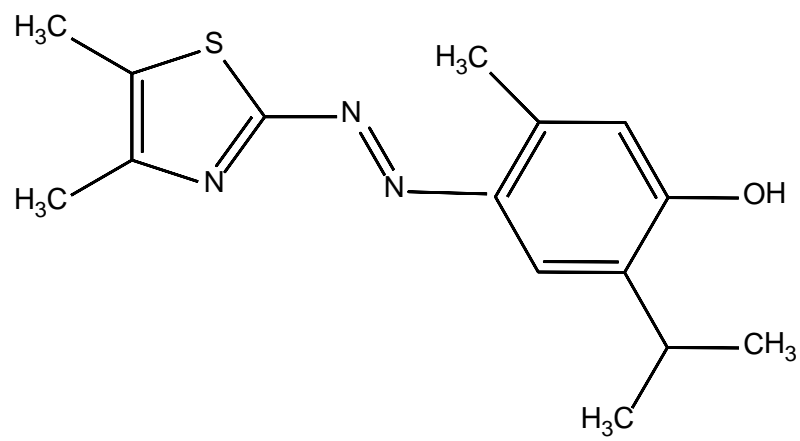

Figure 3. Ligand L. 


\section{Material and Method}

All materials used are of high analytical grade. Melting points were determined in an open capillary tube on a Gallenkamp (Variable heater) melting point apparatus. The infrared spectra of all synthesized products were obtained using Agilent Cary 630 FTIR. Magnetic susceptibility measurement of the metal complexes was obtained using a MSB Mk1 magnetic susceptibility balance, Sherwood Scientific with $\left[\mathrm{HgCo}(\mathrm{SCN})_{4}\right]$ as standard. The electronic spectra, of all the compounds, were obtained in solution, in the wavelength range $400-1000 \mathrm{~nm}$ using 1800 Shimadzu ultra-violet spectrophotometer. The metal analyses for all synthesized compounds were obtained using titrimetric method using EDTA. The ability of the synthesized compounds to act as enzyme inhibitors, towards potential anti-inflammatory ability, was evaluated by carrying out in vitro xanthine oxidase and lipoxygenase inhibitory assay of the synthesized compounds. The anti-inflammatory studies of the compounds were carried out by assessing their red blood cell membrane stabilization and albumin denaturation inhibitory activity. The compounds were synthesized according to an adaptation of previously reported procedure [33]. The synthetic procedure adopted to obtain the target ligand is depicted in Scheme 1. The equations of the reactions for the coordination compounds are given in Equations (1)-(5).

$$
\begin{gathered}
\mathrm{CuCl}_{2}+2 \mathbf{L} \rightarrow \mathrm{CuL}_{2}\left(\mathrm{H}_{2} \mathrm{O}\right)_{2} \text { (Compound 1) } \\
\mathrm{MnCl}_{2}+2 \mathbf{L} \rightarrow \mathrm{MnL}_{2}\left(\mathrm{H}_{2} \mathrm{O}\right)_{2} \text { (Compound 2) } \\
\mathrm{ZnCl}_{2}+2 \mathbf{L} \rightarrow \mathrm{ZnL}_{2} \quad \text { (Compound 3) }
\end{gathered}
$$
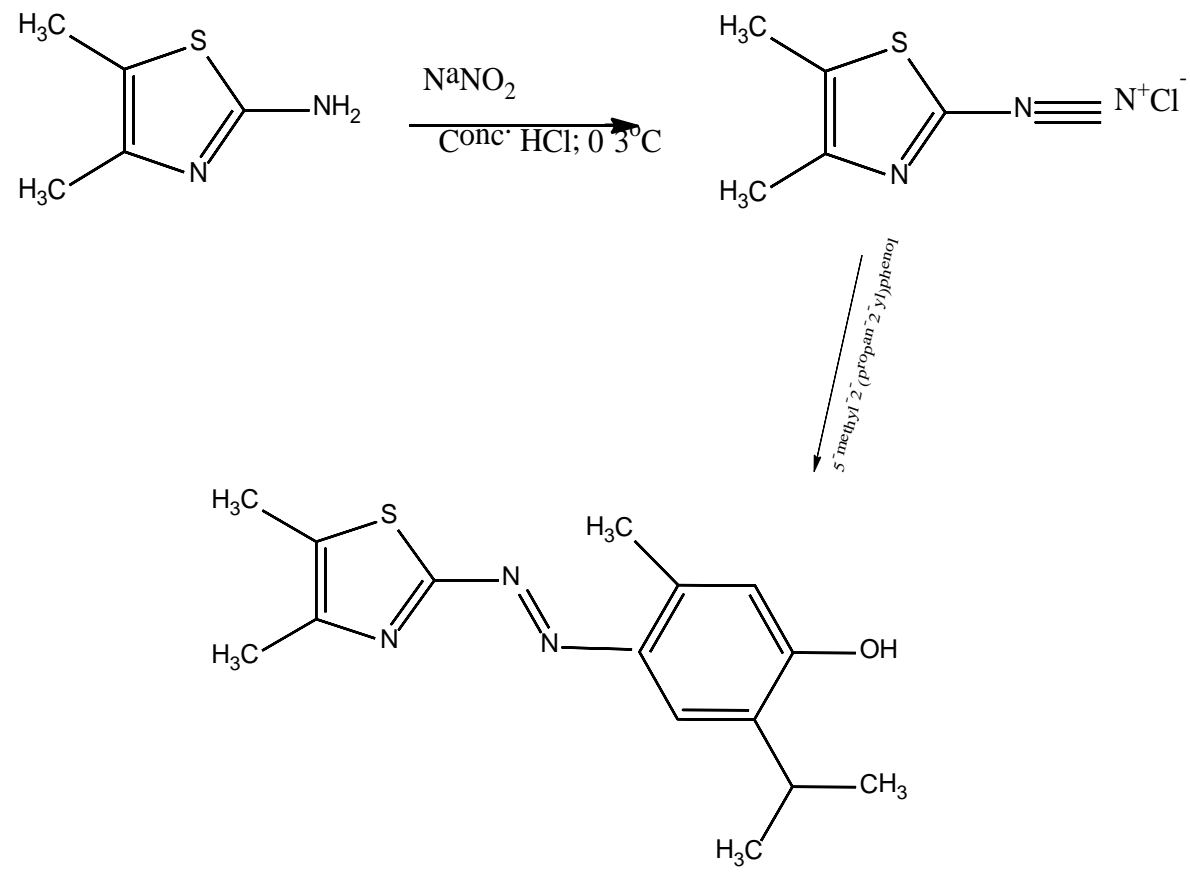

Scheme 1. Schematic representation for the synthesis of ligand L. 


$$
\begin{gathered}
\mathrm{NiCl}_{2}+2 \mathbf{L} \rightarrow \mathrm{NiL}_{2}\left(\mathrm{H}_{2} \mathrm{O}\right)_{2} \quad \text { (Compound 4) } \\
\mathrm{CoCl}_{2}+2 \mathbf{L} \rightarrow \mathrm{CoL}_{2} \quad(\text { Compound } \mathbf{5})
\end{gathered}
$$

\subsection{Synthesis of Heterocyclic Azo Dye Ligand L}

The new hetrocyclic thiazolylazo dye ligand was synthesized by the diazotization coupling reaction using an adaptation of the method as described by Al-adilec and Adnan, 2017 [33]. 2-Amino-4,5-dimethylthiazole (1.28 g, $0.01 \mathrm{M})$ was dissolved in a mixture of $30 \mathrm{~mL}$ distilled water and $4 \mathrm{~mL}$ of concentrated hydrochloric acid $(12 \mathrm{M})$ with continuous stirring and cooling, to about $0^{\circ} \mathrm{C}-3^{\circ} \mathrm{C}$, for an hour. A solution of sodium nitrite $(0.83 \mathrm{~g}, 0.012 \mathrm{M})$ in $25 \mathrm{~mL}$ distilled water was added dropwise to the resultant mixture with stirring for 20 mins, with a drop rate of $\approx 1.25 \mathrm{~mL} / \mathrm{s}$. The mixture obtained was then left for about 20 mins in order for the reaction to attain completion and the cation obtained becomes stable. The resulting diazonium chloride solution was added drop-wise with constant stirring, to a solution of 5-methyl-2-(propan-2-yl)phenol $(1.50 \mathrm{~g}, 0.01 \mathrm{M})$ dissolved in $75 \mathrm{ml}$ alkaline ethanol, sodium hydroxide (14 mL, 7\%). The mixture was cooled to $0^{\circ} \mathrm{C}$ and stirred for a further $2 \mathrm{~h}$ in an ice bath at $(0-2)^{\circ} \mathrm{C}$. The crude product was filtrated and washed with distilled water to afford an orange product. This was recrystallized using methanol/water mixture $(70 / 30, \mathrm{v} / \mathrm{v})$, filtered and dried at $60^{\circ} \mathrm{C}$. Yield: $2.46 \mathrm{~g}, 72.28 \%$; m.pt: $240^{\circ} \mathrm{C}-241^{\circ} \mathrm{C}(\mathrm{d})$. The product obtained was soluble in water and insoluble in ethanol and methanol.

\subsection{Syntheses of Metal Complexes}

\subsubsection{Compound 1}

Copper(II) chloride $(0.89 \mathrm{~g}, 0.005 \mathrm{M})$ was dissolved in aqueous ethanol. A solution of ligand L ( $5.92 \mathrm{~g}, 0.01 \mathrm{M}$ ) was obtained by dissolving it in warm ethanol, $30 \mathrm{ml}$ hot buffer (ammonium acetate) solution at $\mathrm{pH} 7$ was then added to this with stirring. The resultant solution was added drop-wise with vigorous stirring to the Copper(II) chloride solution. The reaction mixture was then refluxed for 4 h. The resulting mixture was then cooled. A pale-yellow precipitate was obtained. This was recrystallized using methanol/water mixture $(10 \mathrm{~mL})$.

Yield: 2.46 g, $72.28 \%$; m.pt: $162^{\circ} \mathrm{C}-163^{\circ} \mathrm{C}$ (d); metal composition (\%): calc.: 9.37; found: $10.24 ; \mu_{\text {eff: }} 1.98 \mathrm{BM}$. The product obtained was soluble in water and insoluble in ethanol, methanol.

Similar procedure was adopted for the syntheses of the following complexes.

\subsubsection{Compound 2}

Manganese(II) chloride tetrahydrate $(1.01 \mathrm{~g}, 0.005 \mathrm{M})$ and ligand $\mathrm{L}(5.92 \mathrm{~g}, 0.01$ M) afforded a pale orange precipitate. Yield: $2.23 \mathrm{~g}, 65.28 \%$; m.pt: $180^{\circ} \mathrm{C}-182^{\circ} \mathrm{C}$; metal composition (\%): calc.: 9.51 ; found: 9.87 ; $\mu_{\text {eff: }} 5.82 \mathrm{BM}$. The product obtained was soluble in water and insoluble in ethanol, methanol.

\subsubsection{Compound 3}

Zinc(II) chloride (0.18 g, $0.005 \mathrm{M})$ and ligand L (5.92 g, $0.01 \mathrm{M})$ afforded an 
orange precipitate. Yield: $2.21 \mathrm{~g}, 69.45 \%$; m.pt: $250^{\circ} \mathrm{C}-251^{\circ} \mathrm{C}(\mathrm{d})$; metal composition (\%): calc.: 8.62; found: 9.28. The product obtained was soluble in water and insoluble in ethanol, methanol.

\subsubsection{Compound 4}

Nickel(II) chloride hexahydrate $(1.21 \mathrm{~g}, 0.005 \mathrm{M})$ and ligand L (5.92 g, $0.01 \mathrm{M}$ ) afforded a light blue precipitate. Yield: $2.35 \mathrm{~g}, 69.23 \%$; m.pt: $248^{\circ} \mathrm{C}-249^{\circ} \mathrm{C}(\mathrm{d})$; metal composition (\%): calc.: 8.71 ; found: 8.56 ; $\mu_{\text {eff: }} 2.98$ BM. The product obtained was soluble in water and insoluble in ethanol, methanol.

\subsubsection{Compound 5}

Cobalt(II) chloride hexahydrate $(1.19 \mathrm{~g}, 0.005 \mathrm{M})$ and ligand L (5.92 g, $0.01 \mathrm{M})$ afforded a light brown precipitate. Yield: $2.64 \mathrm{~g}, 71.85 \%$; m.pt: $201^{\circ} \mathrm{C}-202^{\circ} \mathrm{C}$ (d); metal composition (\%): calc.: 9.19; found: 9.54; $\mu_{\text {eff: }} 2.26$ BM. The product obtained was soluble in water and insoluble in ethanol, methanol.

\subsection{Enzyme Inhibition Studies}

\subsubsection{In Vitro Xanthine Oxidase Inhibition Assay}

The Xanthine Oxidase (XO) inhibitory activity of ligand L and compounds 1-5 was assayed spectrophotometrically under aerobic conditions as described by Nguyen et al. 2006, with some modifications [40]. The assay was carried out at five different concentrations ranging from $0.03125,0.0625,0.125,0.25,0.5$ to 1 $\mathrm{mg} / \mathrm{L}$ for the samples. These were directly dissolved in phosphate buffer-MeOH (1\%) and screened for xanthine oxidase inhibitory activity at final concentration of $50 \mu \mathrm{g} / \mathrm{mL}$. The mixture assay consisted of $150 \mu \mathrm{L}$ phosphate buffer $(1 / 15 \mathrm{M}$, $\mathrm{pH} 7.5), 50 \mu \mathrm{l}$ sample solution and $50 \mu \mathrm{l}$ enzyme solution $(0.28$ units/mL in phosphate buffer). The reaction was initiated by adding $250 \mu \mathrm{L}$ of substrate solution (0.15 mM in water). Enzymatic kinetic was recorded at $295 \mathrm{~nm}$ for $02 \mathrm{~min}$. The negative control was prepared and consisted of $1 \%$ methanol solution without the samples. Allopurinol a well-known inhibitor of xanthine oxidase was used as a positive control at a final concentration of $50 \mu \mathrm{g} / \mathrm{mL}$. All experiments were performed in triplicate. Xanthine oxidase inhibitory activity was expressed as the percentage inhibition of xanthine oxidase, calculated as (\%) inhibition following Equation (1) and the $\mathrm{IC}_{50}$ values were determined. The $\mathrm{IC}_{50}$ values were calculated from the mean values of data from four determinations.

$$
(\%) \text { inhibition }=(1-B / A) \times 100
$$

where:

$A$ is the change in absorbance of the assay without the sample ( $\Delta \mathrm{abs}$. with enzyme- $\Delta$ abs. without enzyme);

$B$ is the change in absorbance of the assay with the sample ( $\Delta$ abs. with enzyme- $\Delta$ abs. without enzyme);

NB: 1 unit of $\mathrm{XO}$ is defined as the amount of enzyme required to produce 1 $\mu \mathrm{mol}$ of uric acid $/ \mathrm{min}$ at $25^{\circ} \mathrm{C}$. 


\subsubsection{In Vitro Lipoxygenase Inhibitory Assay}

Lipoxygenase inhibitory activity of ligand $\mathrm{L}$ and compounds 1-5 with linoneic acid as substrate was measured with a UV/visible spectrophotometer as described by Gunathilake et al., 2018, with some modifications [15]. The assay was carried out at five different concentrations ranging from $0.03125,0.0625,0.125,0.25,0.5$ to $1 \mathrm{mg} / \mathrm{L}$ for the samples. The samples were screened for lipoxygenase inhibitory activity at final concentration of $50 \mu \mathrm{g} / \mathrm{mL}$. The assay mixture consisted of $150 \mu \mathrm{l}$ phosphate borate ( $1 / 15 \mathrm{M}, \mathrm{pH} 7.5), 50 \mu \mathrm{L}$ of each sample solution and 50 $\mu \mathrm{L}$ lipoxygenase solution $(0.28 \mathrm{U} / \mathrm{ml}$ in phosphate borate). The reaction was initiated by adding $250 \mu \mathrm{L}$ of linoneic acid solution $(0.15 \mathrm{mM}$ in water). Enzymatic kinetic was recorded at $234 \mathrm{~nm}$ for $02 \mathrm{~min}$. The negative control contained 1\% methanol solution, without sample solution, to the above mixture. All experiments were performed in triplicate. Lipoxygenase inhibitory activity was expressed as the percentage inhibition of lipoxygenase, calculated as (\%) inhibition following Equation (6). Quercetin was used as the positive reference drug. The $\mathrm{IC}_{50}$ values were calculated from the mean values of data from four determinations.

\subsection{Anti-Inflammatory Studies}

\subsubsection{Assay of Red Blood Cell Membrane Stability Activity}

1) Preparation of Red Blood Cells (RBC)

The bovine red blood cell was prepared according to the method of Mohamed et al., 2014 [16]. Fresh bovine blood was mixed with an anti-coagulant (3.8\% tri-sodium citrate) in a clean bottle in ratio 2:1 (blood: anti-coagulant) and mixed gently by inversion. The blood sample was centrifuged at $3000 \mathrm{rpm}$ on a bench centrifuge, Model 90-2, for $10 \mathrm{~min}$. at room temperature. The supernatant layer (plasma and leucocytes) was carefully removed while the packed red blood cell was washed again in fresh normal saline $(0.85 \% \mathrm{w} / \mathrm{v} \mathrm{NaCl})$. The process of washing and centrifugation was repeated several times until the supernatant layer was clear (colourness). Bovine erythrocytes $(2 \% \mathrm{v} / \mathrm{v})$ were then prepared by diluting $2 \mathrm{~mL}$ of packed cell with normal saline to $100 \mathrm{~mL}$. This was kept undisturbed at $4^{\circ} \mathrm{C}$ in the refrigerator.

\section{2) RBC Membrane Stabilization Assay}

The membrane stabilizing activity for ligand $\mathrm{L}$ and compounds 1-5, was carried out according to the modified procedure as described by Oyedapo et al., 2010 [41]. The assay mixture consisted of hyposaline $(1.0 \mathrm{~mL}), 0.15 \mathrm{M}$ phosphate buffer, pH $7.4(0.5 \mathrm{~mL})$ of varying volumes of solutions of the samples (0 $1000 \mu \mathrm{g}), 0.5 \mathrm{~mL}$ of $2 \%(\mathrm{v} / \mathrm{v})$ erythrocyte to give a final volume of $3.0 \mathrm{~mL}$. The reaction mixture was incubated at $56^{\circ} \mathrm{C}$ for $30 \mathrm{~min}$. The tubes with the mixture were then cooled and centrifuged at $3000 \mathrm{rpm}$ for $10 \mathrm{~min}$. The supernatants obtained were collected and the absorbance was monitored at $560 \mathrm{~nm}$ against a reagent blank.

The percentage stability was estimated as follows: 


$$
\begin{aligned}
& \% \text { membrane stability } \\
& =\left\{100-\frac{(\text { Abs of test drug }- \text { Abs of drug control })}{\text { Abs of blood control (blank) }- \text { Abs of drug control }} \times 100\right\}
\end{aligned}
$$

The blood control used was diclofenac, this represents 100\% lysis.

\subsubsection{Protein Denaturation Inhibitory Activity Assay}

Protein (albumin) denaturation assay was done according to the method described by Gambhire et al., 2009 [42], with some modifications as described in Gunathilake et al., 2018 [15]. The synthesized compounds and positive standard (diclofenac) were prepared at a concentration of $0.1 \%$ each $(1.0 \mathrm{mg} / \mathrm{ml})$. The reaction mixture $(5 \mathrm{~mL})$ consisted of $0.2 \mathrm{~mL}$ of $1 \%$ bovine albumin, $4.78 \mathrm{~mL}$ of phosphate buffered saline (PBS, pH 6.4), and $0.02 \mathrm{~mL}$ sample of the synthesized compounds, and the mixture was mixed, and was incubated in a water bath $\left(37^{\circ} \mathrm{C}\right)$ for $15 \mathrm{~min}$, and then the reaction mixture was heated at $70^{\circ} \mathrm{C}$ for $5 \mathrm{~min}$. After cooling, the turbidity was measured at $660 \mathrm{~nm}$ using a UV/VIS spectrometer (Optima, SP-3000, Tokyo, Japan). Phosphate buffer solution was used as the control. The percentage inhibition of protein denaturation was calculated by using the following formula:

$$
\text { \%inhibition of denaturation }=100 \times\left(1-A_{2} / A_{1}\right)
$$

where $A_{1}=$ absorption of the control sample, and $A_{2}=$ absorption of the test sample.

\subsection{Statistical Analysis}

All data are presented as the mean \pm standard deviation for all in vitro assays tested, and each analysis was done in triplicate. One-way analysis of variance (ANOVA) was performed using MINITAB15 software and Pearson's correlation coefficient $(r)$.

\section{Result and Discussion}

\subsection{Structural Analysis}

\subsubsection{Ligand}

The FTIR spectrum of ligand L (Figure 4) exhibited a weak broad band at 3529 $\mathrm{cm}^{-1}$ ascribable to the stretching absorption frequency of the hydroxyl substituent [43] [44] [45]. This was further supported by bands observed at 1379 and $1148 \mathrm{~cm}^{-1}$ which were assigned to $\delta(\mathrm{O}-\mathrm{H})$ and $v(\mathrm{C}-\mathrm{OH})$ absorption frequencies respectively [43] [44] [45]. Weak extended sharp bands in the high energy region of the spectrum suggest hydrogen bonding. This may be attributed to intermolecular interaction between phenolic substituents of molecules of ligand $\mathrm{L}$. The spectrum was devoid of absorption band attributable to the amino $\left(-\mathrm{NH}_{2}\right)$ substituent present in 2-amino-4,5-dimethylthiazole, one of the reactants. This therefore suggest the diazotization of the heterocyclic amine and plausible coupling of this with 5-methyl-2-(propan-2-yl)phenol. This was however confirmed by the appearance of the $\mathrm{N}=\mathrm{N}$ absorption band observed at $1446 \mathrm{~cm}^{-1}$ 
(Table 1) [43] [44] [45]. The appearance of this absorption band at the observed frequency, lower than that expected, suggests conjugation with the heterocyclic imine at one end and the aromatic phenol at the other end [43] [44] [45]. It should be noted that this frequency was absent in the spectrum of all the reagents. Additional evidence for the formation of the thiazolylazo dye ligand was obtained as a result of the band observed at $1543 \mathrm{~cm}^{-1}$ attributable to $v(\mathrm{~N}=-\mathrm{N})$ $+v(\mathrm{~N}=\mathrm{C})$ [43]. Corroborating this further was the $v(\mathrm{C}=\mathrm{N})$ at $1576 \mathrm{~cm}^{-1}$ [43] [44] [45].

The electronic spectrum in the ultraviolet region exhibited three intense bands at 290, 324 and $477 \mathrm{~nm}$ (Table 2) ascribable to $n \rightarrow \sigma^{\star}, \pi \rightarrow \pi^{*}$ and $n \rightarrow \pi^{*}$ of the major chromophores of the ligand; the phenolic $-\mathrm{OH}, \mathrm{C}=\mathrm{N}$ and $\mathrm{N}=\mathrm{N}$ substituents [44] [45]. The first band is assignable to transition in the phenolic substituent [44]. The second transition is suggested to originate from the imine substituent which is in conjugation thiazole ring as well as the azo moiety [45]. The third band is attributable to transition due to the $\mathrm{N}=\mathrm{N}$ substituent in addition to intermolecular charge transfer taken from the phenolic ring through the azo group [45].

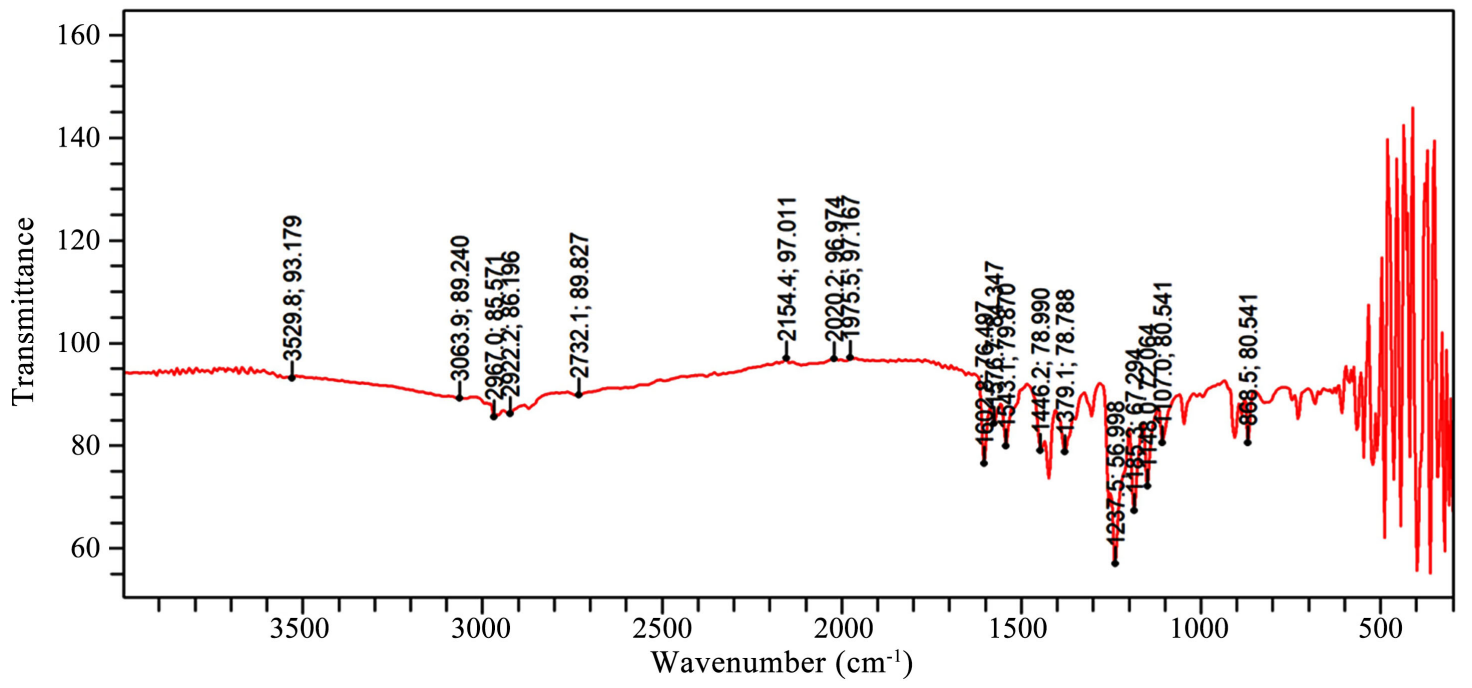

Figure 4. FTIR spectrum of ligand L.

Table 1. Relevant infrared spectra bands for the ligands and complexes $\left(\mathrm{cm}^{-1}\right)$.

\begin{tabular}{ccccccc}
\hline Band & L & $\mathbf{1}$ & $\mathbf{2}$ & $\mathbf{3}$ & $\mathbf{4}$ & $\mathbf{5}$ \\
\hline$v(\mathrm{O}-\mathrm{H})$ & 3529 & 3529,3347 & $3794 \mathrm{w}, 3406 \mathrm{~b}, \mathrm{tr}$ & 3391 & 3794 & 3585 \\
$v(\mathrm{C}-\mathrm{H})$ & 3063 & 3127 & 3170 & 3175 & 3175,3060 & \\
$v(\mathrm{C}=\mathrm{C})$ & 1602 & 1602 & 1599 & 1599 & 1602 & 1606 \\
$v(\mathrm{C}=\mathrm{N})$ & 1576 & 1558 & 1636,1532 & 1636 & 1636 & 1543,1572 \\
$v(\mathrm{~N}=\mathrm{N})$ & 1446 & 1423 & 1435 & 1438 & 1490,1435 & 1423 \\
$v(\mathrm{C}-\mathrm{S})$ & 1237 & 1304,1252 & 1271 & 1255 & 1237 & 1237 \\
$\delta(\mathrm{O}-\mathrm{H}) \mathrm{Ar}$ & 1379 & 1367 & 1379 & 1379 & 1323 & 1379 \\
$\delta(\mathrm{C}-\mathrm{N})$ & 1185 & 1252 & 1237 & 1241 & 1241,1203 & 1185 \\
$v(\mathrm{M}-\mathrm{O})$ & & 674,607 & 674,629 & - & 670,629 & 682 \\
$v(\mathrm{M}-\mathrm{N})$ & & 540 & 570 & 521 & 570,529 & 555 \\
\hline
\end{tabular}


Table 2. Electronic spectra bands (nm), for the ligands and complexes.

\begin{tabular}{ccc}
\hline Compound & Bands 1, 2, 3, 4 nm & d-d \\
\hline L & $290,324,477$ & - \\
$\mathbf{1}$ & $285,373,487$ & 525 shld, 683, 884 \\
$\mathbf{2}$ & 230,320 & $521,617,864$ \\
$\mathbf{3}$ & 320,340 & - \\
$\mathbf{4}$ & $209,309,372,460$ & 815 \\
$\mathbf{5}$ & $265,323,422$ & 769 \\
\hline
\end{tabular}

\subsubsection{Compound 1}

The Fourier transformed infrared spectrum of the complex exhibited two broad bands at 3529 and $3347 \mathrm{~cm}^{-1}$ attributable to $v(\mathrm{O}-\mathrm{H})$ (Table 1) [43] [44] [45]. The former frequency occurred at the same frequency as the free base. This therefore suggests that coordination did not occur via this functional group within the ligand [43]. The latter frequency occurred lower than that observed for the free base. This is suggestive of coordination of solvent from the reaction medium. This was corroborated with the frequency bands observed at 1185 and $1043 \mathrm{~cm}^{-1}$ ascribed to $\delta(\mathrm{O}-\mathrm{H})$ and $v(\mathrm{M}-\mathrm{OH})$ for the solvent. According to Pavia et al. 2001, a distinguishing feature between a phenolic and other hydroxyl substituent is the frequency at which the $\delta(\mathrm{O}-\mathrm{H})$ and $v(\mathrm{C}-\mathrm{OH})$ are observed [44]. For phenolic $-\mathrm{OH}$ the $\delta(\mathrm{O}-\mathrm{H}) \mathrm{Ar}$ and $v(\mathrm{C}-\mathrm{OH})$ are observed at higher energy as a result of the oxygen atom in conjugation with the double bond from the ring. In this case both $\delta(\mathrm{O}-\mathrm{H})$ and $v(\mathrm{C}-\mathrm{OH})$ were observed and the one observed at higher frequency at $1367 \mathrm{~cm}^{-1}$ was ascribed to the $\delta(\mathrm{O}-\mathrm{H})$, with the lower frequency at $1110 \mathrm{~cm}^{-1}$ due to $v(\mathrm{C}-\mathrm{OH})$ of the phenolic moiety [43] [44] [45]. Bands observed at 674 and $607 \mathrm{~cm}^{-1}$ were attributed to $v(\mathrm{M}-\mathrm{O})$ [46] [47] [48]. This further supported the coordination of oxygen atoms of the solvent molecule to the metal ion [43]. Evidence for the coordination of the imine moiety was provided by the band observed at $1558 \mathrm{~cm}^{-1} v(\mathrm{C}=\mathrm{N})$. A shift of $80 \mathrm{~cm}^{-1}$ was observed for the $v(\mathrm{~N}=\mathrm{N})$ in comparison with the free ligand as a consequence this suggested coordination of a nitrogen atom of the azo functional group [43]. Additional evidence for the coordination of nitrogen atoms to the metal ion was provided by the frequency band observed at $540 \mathrm{~cm}^{-1}$ attributable to $\mathrm{Cu}$-nitrogen stretching frequency [49].

The electronic spectrum of compound 1 elicited six bands. In the ultra violet region, the spectrum displayed three intense bands at 285,373 and $487 \mathrm{~nm}$. These were ascribed to $n \rightarrow \sigma^{\star}, \pi \rightarrow \pi^{*}$ and $n \rightarrow \pi^{*}$ intraligand transitions of the major chromophores of the ligand [43] [44]. This is indicative of a bathochromic shift for the least wavelength and hysochromic shifts for the other two wavelengths. As a result, it suggests possible coordination of ligand $\mathrm{L}$ to the metal ion [43]. In the visible region a shoulder was observed at $525 \mathrm{~nm}$ and assigned to ${ }^{2} \mathrm{~B}_{1 \mathrm{~g}} \rightarrow{ }^{2} \mathrm{~A}_{1 \mathrm{~g}}$ transition [50] [51]. In addition to this, two bands were also observed at 683 and $884 \mathrm{~nm}$ and attributed to ${ }^{2} \mathrm{~B}_{1 \mathrm{~g}} \rightarrow{ }^{2} \mathrm{~B}_{2 \mathrm{~g}}$ and ${ }^{2} \mathrm{~B}_{1 \mathrm{~g}} \rightarrow{ }^{2} \mathrm{E}_{\mathrm{g}} \mathrm{d}-\mathrm{d}$ transitions [50] [51]. It should however be noted that the electronic spectrum of ligand $\mathrm{L}$ did not 
exhibit absorption bands in the visible region. This appearance of new absorption bands, in the visible region of the spectrum, which were absent in the ligand's, indicated coordination of the metal ion with ligand L [43]. The transitions are consistent with a Jahn Teller distorted octahedral geometry around $\mathrm{Cu}$ (II) ion. The magnetic moment obtained at $1.98 \mathrm{BM}$, indicative of a tetragonally distorted octahedral geometry for a $3 \mathrm{~d}^{9}$ configuration for a $\mathrm{Cu}(\mathrm{II})$ ion, further affirmed this geometry [52].

\subsubsection{Compound 2}

The FTIR spectrum for compound 2 (Figure 5) displayed two bands at the high energy region. A weak band was observed at $3794 \mathrm{~cm}^{-1}$, the second was a broad band with the shape of a trough observed at $3406 \mathrm{~cm}^{-1}$. The first band may be ascribed to the phenolic $v(\mathrm{O}-\mathrm{H})$ with intermolecular hydrogen bonding [43] [44] [45]. This was corroborated by the $\delta(\mathrm{O}-\mathrm{H}) \mathrm{Ar}$ observed at $1379 \mathrm{~cm}^{-1}$ and $v(\mathrm{C}-\mathrm{OH})$ at $1148 \mathrm{~cm}^{-1}$. The lower energy band may be ascribed to $v(\mathrm{O}-\mathrm{H})$ from water the reaction medium as a result of its shape [43] [44] [45]. This was supported by $\delta(\mathrm{O}-\mathrm{H})$ and $v(\mathrm{C}-\mathrm{OH})$ frequency bands observed at 1181 and $1051 \mathrm{~cm}^{-1}$. It was further corroborated by the appearance of two bands in the far infrared at 674 and $629 \mathrm{~cm}^{-1}$. Attributed to (Mn-O) vibrational frequency [49]. The $v(\mathrm{~N}=\mathrm{N})$ was observed at $1435 \mathrm{~cm}^{-1}$ indicative of a bathchromic shift in comparison with that obtained in the free ligand and therefore suggested coordination of one of the nitrogen atoms of the azo moiety in the ligand to the metal ion [43]. This was supported by the band observed at $570 \mathrm{~cm}^{-1}$ ascribed to the $v(\mathrm{Mn}-\mathrm{N})$. Additionally, two bands with medium intensities were observed at 1636 and 1532 $\mathrm{cm}^{-1}$ and were assigned to $v(\mathrm{C}=\mathrm{N})$ and $v(\mathrm{~N}=\mathrm{C})+v(\mathrm{~N}=\mathrm{N})$. The former stretching frequency indicated a hysochromic shift of $60 \mathrm{~cm}^{-1}$ in comparison with the ligand. Therefore, it points to the fact that the azomethine nitrogen atom present within the thiazole ring participated in coordination of the metal ion with the ligand [43].

The electronic spectrum of this compound exhibited two intense bands at the ultraviolet region at 230 and $320 \mathrm{~nm}$ (Table 2). Assigned to $\mathrm{n} \rightarrow \sigma^{*}$ and $\pi \rightarrow \pi^{*}$ intraligand transitions [44] [45]. Three bands with low intensities were observed at the low energy region at 521, 617 and $864 \mathrm{~nm}$. These were attributed to ${ }^{6} \mathrm{~A}_{1 \mathrm{~g}} \rightarrow{ }^{4} \mathrm{E}_{1 \mathrm{~g}}(\mathrm{G}),{ }^{6} \mathrm{~A}_{1 \mathrm{~g}} \rightarrow{ }^{4} \mathrm{~T}_{1 \mathrm{~g}}(\mathrm{G})$ and ${ }^{6} \mathrm{~A}_{1 \mathrm{~g}} \rightarrow{ }^{4} \mathrm{~T}_{1 \mathrm{~g}}(\mathrm{G}) \mathrm{d}$-d transitions of the central metal ion [50] [51]. The transitions are in agreement with an octahedral geometry for a $\mathrm{d}^{5}$ configuration for $\mathrm{Mn}(\mathrm{II})$ [49] [50] [51].

According to Greenwood and Earnshaw, the explanation of these features stems from the fact that any electronic $\mathrm{d}-\mathrm{d}$ transition from a high spin $\mathrm{d}^{5}$ configuration must of necessity involve the pairing of some electron spins [51]. It follows therefore that such transitions are spin and orbital forbidden and that the absorptions should be of extremely low intensity [50] [51]. That they occur at all is due to weak spin-orbit coupling. The magnetic moment of $5.82 \mathrm{BM}$, indicative of high spin $3 \mathrm{~d}^{5}$ configuration for $\mathrm{Mn}(\mathrm{II})$, this therefore further validates the octahedral geometry for this compound [49] [50] [51]. 


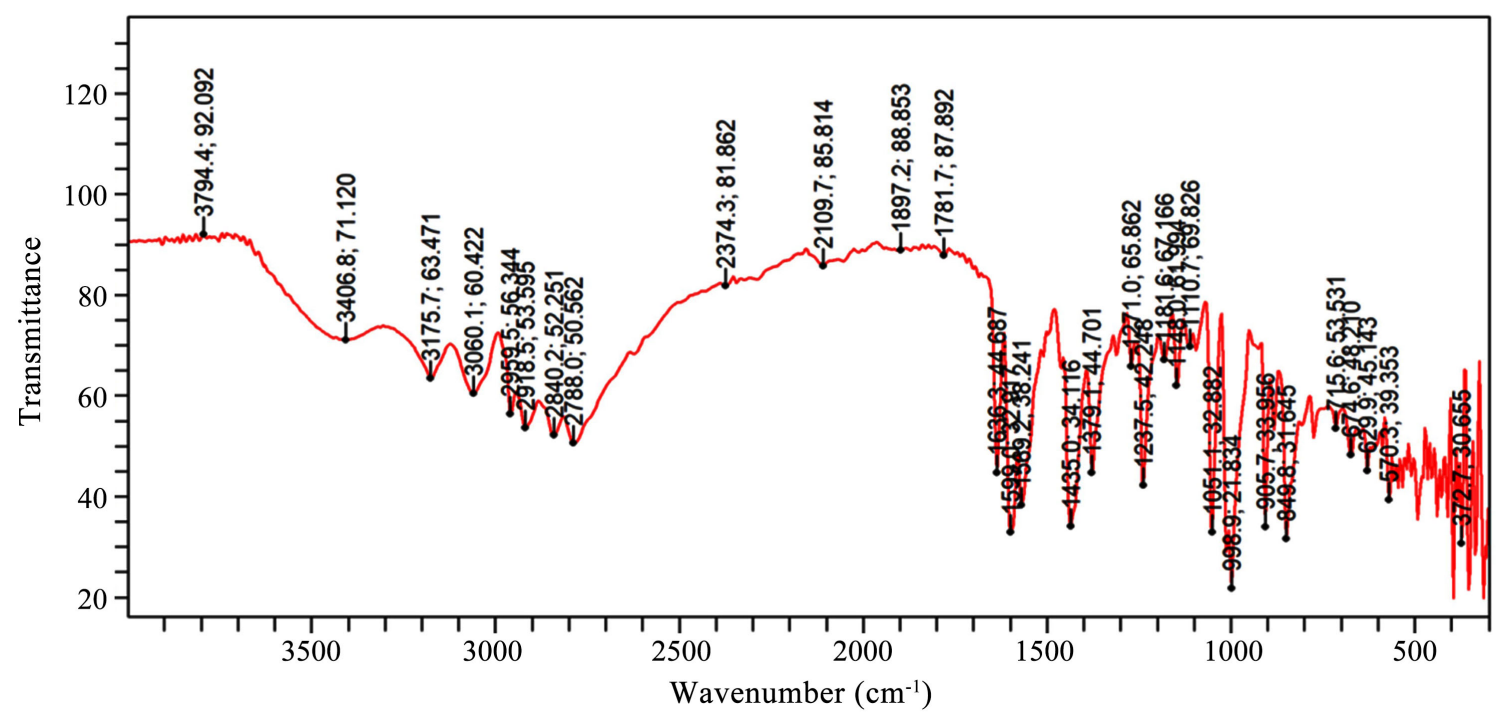

Figure 5. FTIR spectrum of compound 1.

\subsubsection{Compound 3}

The infrared spectrum of this compound (Figure 6) showed a broad band at $3391 \mathrm{~cm}^{-1}$ corresponding to $v(\mathrm{O}-\mathrm{H})$ of the phenol substituent [43] [44] [45]. This was supported by bands observed at 1379 and $1054 \mathrm{~cm}^{-1}$ which were assigned to $\delta(\mathrm{O}-\mathrm{H}) \mathrm{Ar}$ and $v(\mathrm{C}-\mathrm{OH})\left[43\right.$ ] [44] [45]. In this case, a $90 \mathrm{~cm}^{-1}$ difference exists between the observed $v(\mathrm{C}=\mathrm{N})$ and that obtained in the ligand. This therefore suggested coordination of the lone pair of electrons bearing nitrogen atom of the imine substituent to the metal ion [43]. This was supported by the absorption band at $1241 \mathrm{~cm}^{-1}$ attributable to $\delta(\mathrm{C}-\mathrm{N})$. Evidence for the coordination of one of the nitrogen atoms of the azo moiety was provided by the frequency band observed at $1438 \mathrm{~cm}^{-1}$ ascribed to the $v(\mathrm{~N}=\mathrm{N})$ [43]. Further support for the coordination of the nitrogen atoms of the ligand was given by the band at $521 \mathrm{~cm}^{-1}$ attributable to the $v(\mathrm{M}-\mathrm{N})$ [43].

Two intense bands were observed in the electronic spectrum of this complex at 320 and $340 \mathrm{~nm}$ (Table 2). Consistent with $\pi \rightarrow \pi^{*}$ and $n \rightarrow \pi^{*}$ intraligand transitions [44] [45]. No distinctive band was observed in the visible region of this spectrum [50] [51]. This is not unexpected as the central metal ion has a completely filled $3 \mathrm{~d}$ orbital i.e. $\mathrm{d}^{10}$ configuration. The magnetic susceptibility measurement for compound 3 showed a diamagnetic behavior. This is in agreement with previous established reports [50] [51].

\subsubsection{Compound 4}

The FTIR of this compound (Figure 7) revealed weak extended bands at the high energy region of the spectrum with a weak peak at $3794 \mathrm{~cm}^{-1}$ ascribed to the phenolic $v(\mathrm{O}-\mathrm{H})$, with intermolecular hydrogen bond [43] [44] [45]. This was supported by the bands at 1323 and $1114 \mathrm{~cm}^{-1}$ which correspond to $\delta(\mathrm{O}-\mathrm{H}) \mathrm{Ar}$ and $v(\mathrm{C}-\mathrm{OH})$ [43] [44] [45]. The $(\mathrm{C}=\mathrm{N})$ frequency band was obtained at $1636 \mathrm{~cm}^{-1}$, the blue shift in comparison with the ligand serve to suggest coordination 


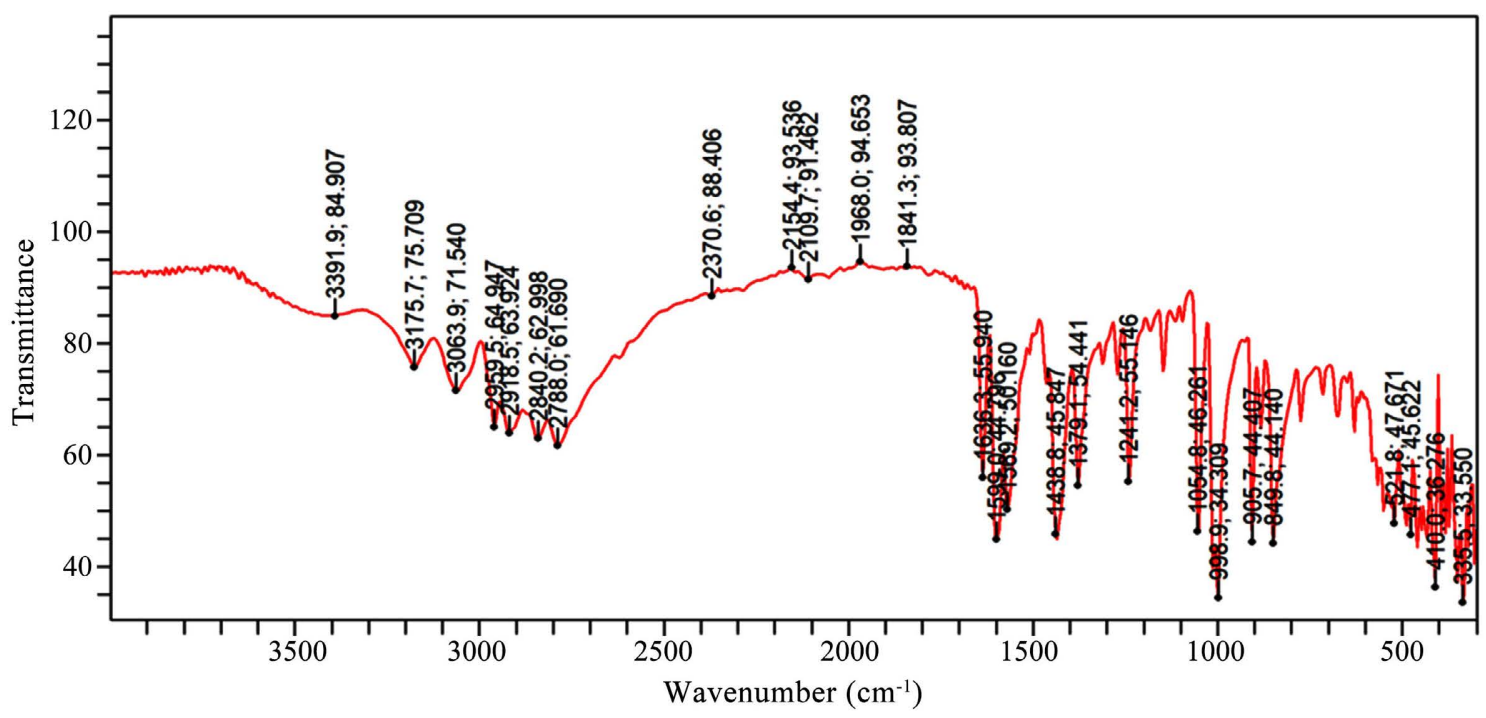

Figure 6. FTIR spectrum of compound 3.

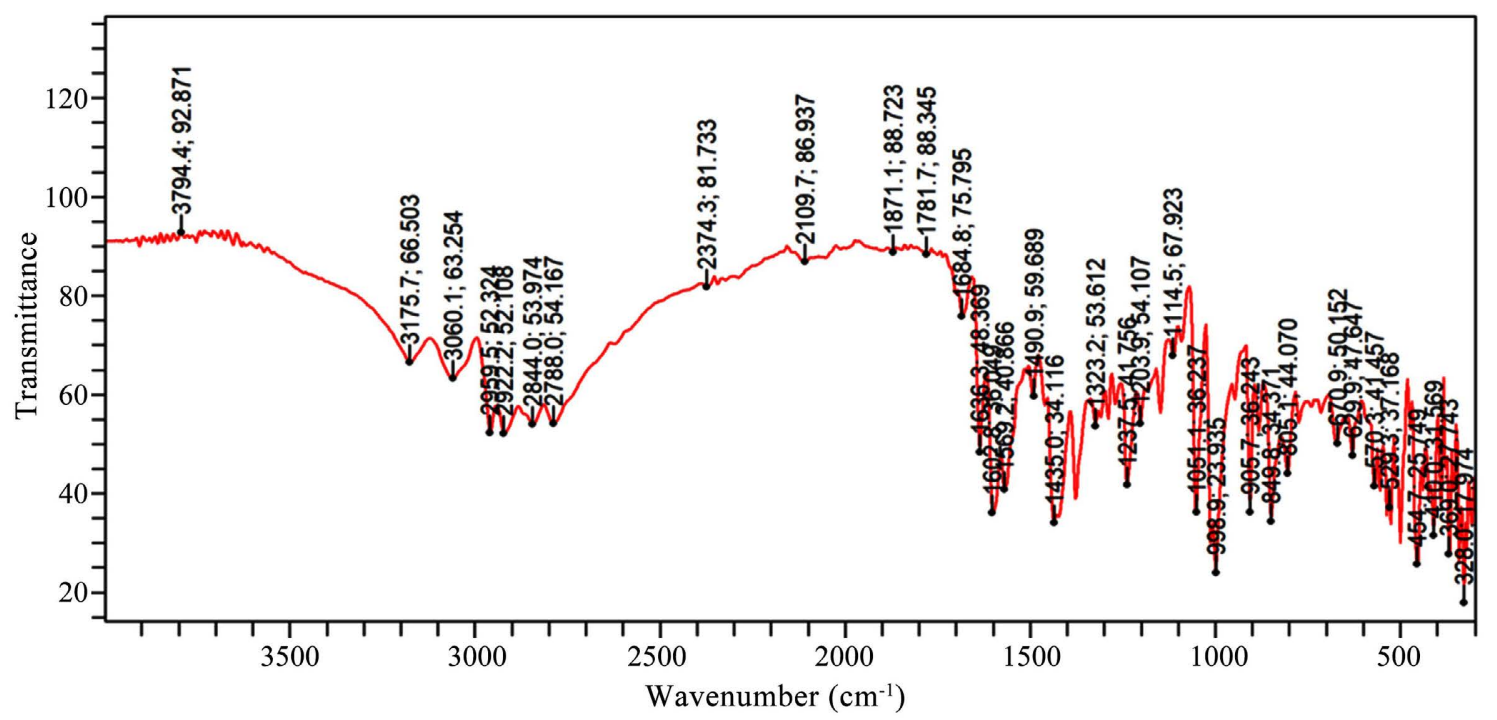

Figure 7. FTIR spectrum of compound 4.

of the nitrogen atom to the metal ion [43]. This was supported by the band observed at $1569 \mathrm{~cm}^{-1}$ ascribable to $v(\mathrm{~N}=-\mathrm{C})+v(\mathrm{~N}=-\mathrm{N})$ [43]. Additional support, was obtained in the $\delta(\mathrm{C}-\mathrm{N})$ with a shift of $56 \mathrm{~cm}^{-1}$, serving as evidence for coordination of the nitrogen atom of the imine substituent [43]. In addition to this, the $v(\mathrm{~N}=\mathrm{N})$ was observed at lower energy in comparison to the ligand at 1435 $\mathrm{cm}^{-1}$. This suggests shortening of the bond and as a consequence it indicated coordination of the ligand via one of the nitrogen atoms of this substituent to the metal ion [43]. This was further supported by the $v(\mathrm{~N}=-\mathrm{N})+v(\mathrm{~N}=-\mathrm{C})$ at $1490 \mathrm{~cm}^{-1}$. Further evidence was provided by the $v(\mathrm{Ni}-\mathrm{N})$ frequency band at 570 and $529 \mathrm{~cm}^{-1}$ [49]. The spectrum also displayed two medium and broad absorption bands at 3175 and $3060 \mathrm{~cm}^{-1}$ with the latter shaped as a trough [43] [44] [45]. These may be attributed to absorption frequencies due to a hydroxyl subs- 
tituent as a result of its shape with overlap with the absorption frequency for $\mathrm{sp}^{3}$ hybridized carbon-hydrogen bond [43] [44] [45]. According to Pavia et al., 2001, the frequency at which this was observed suggests the presence of hydrogen bonding [44]. This was further supported by the appearance of bands at 1203, 1185 and $1051 \mathrm{~cm}^{-1}$ attributable to $\delta(\mathrm{O}-\mathrm{H}), v(\mathrm{C}-\mathrm{O})$ and $\delta(\mathrm{M}-\mathrm{O}-\mathrm{H})$. They therefore suggest coordination of the metal ion with the reaction solvent. Buttressing this were the bands observed at 670 and $629 \mathrm{~cm}^{-1}$ which are due to nickel-oxygen stretching frequencies [43] [49].

Three intense bands were observed in the ultraviolet region of the electronic spectrum for this compound. They were observed at 209, 309 and $372 \mathrm{~nm}$ (Table 2). Attributed to $n \rightarrow \sigma^{*}, \pi \rightarrow \pi^{*}$ and $n \rightarrow \pi^{*}$ intraligand transitions [44] [45]. Two broad bands were observed at 460 and $769 \mathrm{~nm}$ in the visible region of the spectrum. These are ascribable to ${ }^{3} \mathrm{~A}_{2 \mathrm{~g}}(\mathrm{~F}) \rightarrow{ }^{3} \mathrm{~T}_{1 \mathrm{~g}}(\mathrm{P})$ and ${ }^{3} \mathrm{~A}_{2 \mathrm{~g}}(\mathrm{~F}) \rightarrow{ }^{3} \mathrm{~T}_{2 \mathrm{~g}}(\mathrm{~F})$, d-d transitions [50] [51]. Indicative of an octahedral geometry [50] [51]. Corroborating this is its magnetic moment of $2.98 \mathrm{BM}$ [49] [50] [51].

\subsubsection{Compound 5}

Extended sharp bands with a weak band was observed in the high energy region of the Fourier transformed infrared spectrum of the complex. The band at 3585 $\mathrm{cm}^{-1}$ is attributable to the vibrational frequency due to hydroxyl substituent in the ligand [43] (Figure 8). In support of this was the band at $1379 \mathrm{~cm}^{-1}$ ascribed to $\delta(\mathrm{O}-\mathrm{H}) \mathrm{Ar}$. The extended bands are suggestive of hydrogen bond relatable to the hydroxyl moiety [44]. In this complex the $v(\mathrm{~N}=\mathrm{N})$ gave a bathochromic shift of about $23 \mathrm{~cm}^{-1}$ in relation with the ligand. This suggest the elongation of the bond, thereby it may serve as evidence of coordination of the ligand to the metal ion [43]. Corroborating this further was similar shift observed in the $v(\mathrm{C}=\mathrm{N})$ to $1572 \mathrm{~cm}^{-1}$. The metal-nitrogen bond observed at $555 \mathrm{~cm}^{-1}$ also stands to confirm the coordination of a nitrogen atom with the cobalt(II) ion. Additional evidence was provided by $v(\mathrm{~N}=\mathrm{C})+v(\mathrm{~N}=\mathrm{N})$ absorption frequency at $1543 \mathrm{~cm}^{-1}$. Bands observed at 1107 and $1047 \mathrm{~cm}^{-1}$ were ascribed to $\delta(\mathrm{O}-\mathrm{H})$ and $v(\mathrm{M}-\mathrm{OH})$ suggest coordination of water molecules. The $v($ Co-M $)$ observed at $682 \mathrm{~cm}^{-1}$ corroborates this further.

In this present case the electronic spectra elicited three intense bands at 265, 323 and $422 \mathrm{~nm}$. These may be ascribed to $n \rightarrow \sigma^{*}, \pi \rightarrow \pi^{*}$ and $n \rightarrow \pi^{*}$ intraligand transitions of the major chromophores of the ligand [44] [45]. Additionally, a broad band was observed near infrared region at $815 \mathrm{~nm}$ which may be assigned as ${ }^{4} \mathrm{~T}_{1 \mathrm{~g}}(\mathrm{~F}) \rightarrow{ }^{4} \mathrm{~T}_{2 \mathrm{~g}}(\mathrm{~F})$ [50] [51]. A magnetic moment of $2.26 \mathrm{BM}$ was obtained for compound 5. This may be interpreted according to previous reports to be attributable to four-coordinate, square planar geometry for a cobalt(II) complex [50] [51] [53] [54].

The diazonium salt obtained with 2-amino-4,5-dimethylthiazole reacted with 5-methyl-2-(propan-2-yl)phenol to give the thiazolylazo dye ligand $\mathbf{L}$ (Scheme 1). A polyfunctional ligand, bearing substitutes with lone pair of electrons viz: $-\mathrm{OH}, \mathrm{C}=\mathrm{N}$ and $\mathrm{N}=\mathrm{N}$ substituents, with potential donor atoms. From the results 


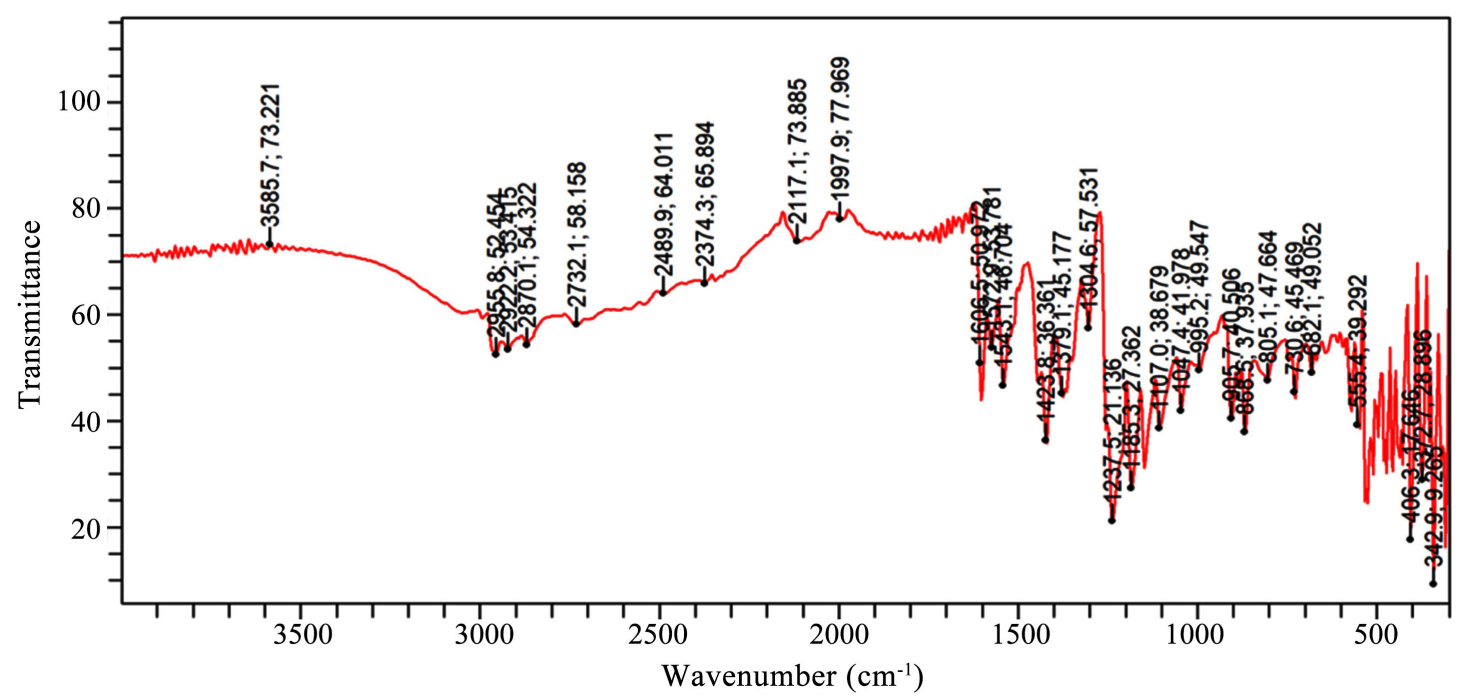

Figure 8. FTIR spectrum of compound 5.

obtained, in the case of compounds 1, 2 and 4 two bands were observed at the high energy region of their spectra and were assigned to the $v(\mathrm{O}-\mathrm{H})$. Initially, one may tend to ascribe both to the asymmetric and symmetric stretching modes for the hydroxyl substituent. However, further analysis of the spectra suggested the presence of water molecule within the coordination sphere of the metal ions. This was alluded to by the presence of absorption frequencies attributable to the $\delta(\mathrm{O}-\mathrm{H})$ and $v(\mathrm{M}-\mathrm{OH})$. The results obtained from the FTIR spectra, was further corroborated by data obtained from their electronic spectra, magnetic susceptibility measurements and metal analyses. Therefore, based on these an octahedral geometry is proposed for these compounds. This is depicted in (Figure 9). In similar vein, the spectrum of compound 5 exhibited only one band for the $v(\mathrm{O}-\mathrm{H})$, it was attributed to the stretching vibrational frequency of the phenolic substituent. Although, in addition to this, frequency bands ascribable to $\delta(\mathrm{O}-\mathrm{H})$, $\delta(\mathrm{O}-\mathrm{H}) \mathrm{Ar}$ and $v(\mathrm{M}-\mathrm{OH})$ were observed. According to Nakamoto et al., 2009, water in inorganic salts may be classified as either lattice or coordination water [43]. There is, however, no definite borderline between the two. The former term denotes water molecules trapped in the crystal lattice, either by weak hydrogen bonds to the anion or by weak coordinate bonds to the metal, or by both. In this case we propose that the water molecule, as suggested from the FTIR spectrum, is lattice water [43]. This is in agreement with that obtained from the electronic spectrum, magnetic moment and percentage metal analysis. Therefore, compound 5 is proposed to assume a square planar geometry (Figure 10). For compound 3, the $\mathrm{Zn}(\mathrm{II})$ complex, the FTIR spectrum exhibited a band for the $v(\mathrm{O}-\mathrm{H})$, $\delta(\mathrm{O}-\mathrm{H}) \mathrm{Ar}$ and $v(\mathrm{C}-\mathrm{OH})$. Contrary to the other compounds, in this case it is interesting to note that similar absorption bands due to coordination of water was absent in this spectrum. The electronic spectrum and magnetic susceptibility measurement data indicated that the complex is diamagnetic. This is not unexpected, as a result of the fully filled penultimate, $3 \mathrm{~d}$ shell. This in collaboration 


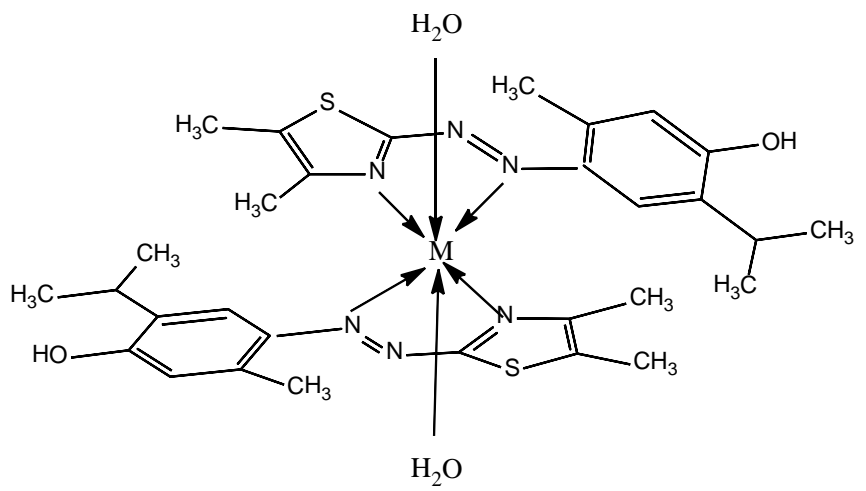

Figure 9. Pictorial representation for compounds 1, 2 and 4; $\mathrm{M}=\mathrm{Cu}$, $\mathrm{Mn}$ and $\mathrm{Ni}$.

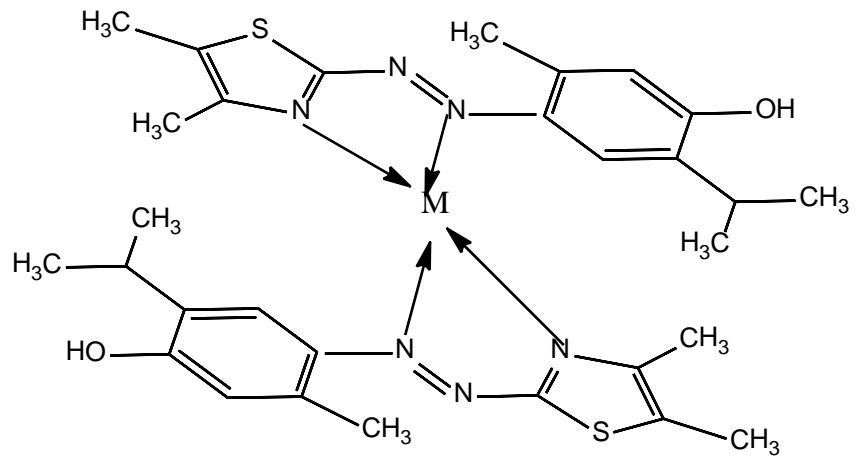

Figure 10. Pictorial representation for compounds 3 and 5; $M=Z n$, Co respectively.

with the FTIR and percentage metal analysis suggest a four-coordinate geometry for this compound. Indicating either a tetrahedral or square planar geometry for this complex. Theoretically a tetrahedral geometry is more readily assumed by this metal ion, to afford $\mathrm{sp}^{3}$ hybridization [50]. However, a square planar geometry is proposed (Figure 10). This is because of the nature of the ligand and more importantly the limited flexibility along the substituents bearing the potential donor atoms.

Additionally, the results obtained suggest that the ligand chelated with the metal ion as a bidentate ligand. It coordinated to the metal ion through the nitrogen atom of the imine substituent and via one of the nitrogen atoms of the azo moiety. Theoretically, coupling of the phenol to the diazonium ion ought to take place at either the ortho or para position, with the ortho position taking precedence if available. The result obtained suggested that this was not the case for ligand L (Figure 3). It is proposed that the diazo-coupling took place at the para position to the phenol substituent in the benzene nucleus of 5-methyl-2-(propan-2-yl)phenol as a result of steric effect.

\subsection{Enzyme Inhibition Studies}

\subsubsection{Xanthine Oxidase Inhibitory Activity}

According to Borges et al., from rheumatological diseases point of view, Xan- 
thine Oxidase (XO) is an enzyme responsible for catalyzing the oxidation of hypoxanthine to xanthine which further leads to the formation of uric acid [40] [55] [56]. When it is elevated above normal level, it has been reported to be the underlying reason of gouty arthritis attack and other inflammatory related diseases [55] [56] [57]. Considering the present study, all the analyzed samples exhibited more than $\geq 50 \%$ inhibition against XO activities at $1.00 \mathrm{mg} / \mathrm{mL}$ concentration. This signifies that the analyzed compounds effectively inhibited XO from catalyzing the action of converting xanthine to uric acid at a considerably low concentration of $0.1 \%$. Compound 2 was found to exert the highest inhibition capacity at this concentration with $75.63 \% \pm 0.001 \%$ inhibitory capacity. It however elicited $\mathrm{IC}_{50}$ at $0.36 \mathrm{~mol} / \mathrm{L}$ (Table 3).

This was followed by compound $1(51.03 \% \pm 0.001 \%)$ with $\mathrm{IC}_{50} 0.52 \mathrm{~mol} / \mathrm{L}$. Following closely is compound 4 , which elicited an inhibitory capacity of $54.22 \%$ $\pm 0.001 \%$ also at this concentration. It however had $\mathrm{IC}_{50}$ of $0.83 \mathrm{~mol} / \mathrm{L}$. On the other hand, ligand L exhibited it highest inhibitory capacity of $54.22 \% \pm 0.001 \%$ at $1.00 \mathrm{mg} / \mathrm{mL}$ with $\mathrm{IC}_{50}$ of $0.85 \mathrm{~mol} / \mathrm{L}$. The order of activity for the analyzed compounds is $2>1>5>4>\mathrm{L}>3$. This observed order suggests that, with respect to inhibition of xanthine oxidase, coordination of metal ions to ligand $\mathrm{L}$ improved the activity of ligand $\mathrm{L}$, with the exception of compound 3 . Therefore, this validates the hypothesis that coordination compounds of biologically active compounds may enhance their activity. The exception of compound 3 in this case indicates that the geometry assumed by the complex and the central metal ion are factors related with the reactivity of coordination compounds [50] [51]. It also reiterates the fact that these factors may be used in fine-tuning coordination compounds towards appropriate usage [58]. The positive control, allopurinol, recorded maximum inhibition of XO activities with $68.36 \%$ at $0.025 \mu \mathrm{g} / \mathrm{mL}$ and $\mathrm{IC}_{50}$ of $7.08 \mathrm{~mol} / \mathrm{L}$. It had been reported previously that samples causing $>50 \% \mathrm{XO}$ enzyme inhibition at concentration of $50 \mu \mathrm{g} / \mathrm{L}$ warranted further investigation (Sweeney, 2001) [59]. Although the compounds tested in this research exhibited relatively good activity, they do not fall within this category.

\subsubsection{Lipoxygenase Inhibitory Activity}

Two important approaches for the design and syntheses of anti-inflammatory agents are based on the inhibition of two enzymes, one of which is lipoxygenase, (LOX). LOX is involved in the biosynthesis of mediators in inflammation. This is because it is involved in the metabolism of arachidonic acid, a precursor to leukotrienes. As a consequence, it is a key target for the development of new anti-inflammatory agents [15] [17] [60] [61] [62] [63]. Results for the lipoxygenase inhibitory activity of ligand $\mathrm{L}$ and compounds $\mathbf{1 - 5}$ are presented in Table 4 . In this case the result obtained points to the fact that ligand $L$ is a better inhibitor of LOX in comparison with the coordination compounds. This therefore suggests that coordination, in case of ligand $\mathrm{L}$, with respect to the metal ions used, may not necessarily improve the LOX inhibitory ability of ligand L. The compounds exhibited a dose dependent activity with the highest activity observed at 1.00 $\mathrm{mg} / \mathrm{mL}$. Inhibition levels were within the range of $6.90 \%-89.35 \%$ within the 
Table 3. Xanthine oxidase inhibitory activity.

\begin{tabular}{cccc}
\hline Compound & $\mathrm{IC}_{50}$ & $\mathrm{SD}$ & SEM \\
\hline $\mathrm{L}$ & 0.854456 & 0.009029 & 0.006384 \\
$\mathbf{1}$ & 0.520345 & 0.030722 & 0.021724 \\
$\mathbf{2}$ & 0.362232 & 0.010108 & 0.007147 \\
$\mathbf{3}$ & 0.855845 & 0.007767 & 0.005492 \\
$\mathbf{4}$ & 0.832874 & 0.063932 & 0.045207 \\
$\mathbf{5}$ & 0.660201 & 0.028611 & 0.020231 \\
\hline
\end{tabular}

Table 4. Lipoxygenase inhibitory activity.

\begin{tabular}{ccc}
\hline Compound & IC $_{50}$ & SD \\
\hline L & 0.220278 & 0.107314 \\
$\mathbf{1}$ & 0.320623 & 0.010894 \\
$\mathbf{2}$ & 0.962777 & 0.170421 \\
$\mathbf{3}$ & 0.848486 & 0.034688 \\
$\mathbf{4}$ & 0.778577 & 0.279866 \\
$\mathbf{5}$ & 0.55096 & 0.004602 \\
\hline
\end{tabular}

concentration of $0.03-1.00 \mathrm{mg} / \mathrm{mL}$. The order of the lipoxygenase inhibitory activity of the assayed compounds was $\mathrm{L}>\mathbf{1}>\mathbf{5}>\mathbf{4}>\mathbf{3}>\mathbf{2}$. Ligand $\mathrm{L}$ exhibited the best activity with $89.35 \% \pm 0.001 \%$ and $\mathrm{IC}_{50}$ of $0.22 \mathrm{~mol} / \mathrm{L}$. It was followed by compound 1 with $71.29 \% \pm 0.001 \%$ with $\mathrm{IC}_{50} 0.32 \mathrm{~mol} / \mathrm{L}$. The least inhibitory activity, at this same concentration, was expressed by compound 2 with $48.70 \%$ $\pm 0.001 \%$ and $\mathrm{IC}_{50}$ of $0.96 \mathrm{~mol} / \mathrm{L}$. The standard, quercetin, similar with the synthesized compounds, elicited a dose dependent inhibitory activity with maximum activity of $71.50 \% \pm 0.001 \%$ at $100 \mu \mathrm{g} / \mathrm{ml}$. It however, gave an $\mathrm{IC}_{50}$ of 55.91 $\mathrm{mol} / \mathrm{L}$.

\subsection{Anti-Inflammatory Studies}

\subsubsection{RBC Membrane Stabilization Assay}

During inflammation, as part of their defensive roles, leukocytes release their lysosomal enzymes, causing further tissue damage and subsequent inflammation [15] [64]. Damage to cell membranes will further make the cell more susceptible to secondary damage by means of free radical-induced lipid peroxidation [15] [65]. Regulation of the volume and water content of cells may occur, through membrane proteins, by controlling the movement of sodium and potassium ions and damage to the membrane will affect this function [15] [64]. As the red blood cell membrane is similar to that of lysosomal membrane, inhibition of red blood cell hemolysis may provide insights into the inflammatory process [21]. Stabilization of these cell membranes may retard or inhibit the lysis and subsequent release of the cytoplasmic contents which, in turn, minimize the tissue damage and, hence, the inflammatory response [15] [64]. Therefore, substances that con- 
tribute significant protection of cell membrane against injurious substances are important in the event of inhibiting the progression of inflammation.

The membrane stabilizing activities of the ligand $\mathrm{L}$ and compounds 1-5 are presented in Table 5(a)-(f). The results showed that the activities of the assayed compounds were higher than that of the standard drugs even at lower concentration ranges. This suggests that they are highly potent on human erythrocyte, adequately protecting it against hypotonic induced lyses. All the tested compounds, i.e. ligand $\mathrm{L}$ and compounds 1-5, showed dose dependent membrane stabilizing activity over all the concentration ranges. Ligand $\mathrm{L}$ exhibited a minimum membrane stability of $38.166 \% \pm 0.27 \%$ at $2 \mathrm{mg} / \mathrm{mL}$ and maximum activity of $91.3199 \%$ $\pm 1.55 \%$, at $0.20 \mathrm{mg} / \mathrm{mL}$. The mode of response of the erythrocyte was both monophasic and biphasic (Table 5(a)). Similarly, the response of the red blood cells to compound 1 was monophasic and biphasic at lower and higher concentrations of the compound, respectively (Table 5(b)). Compound 1 exerted a minimum membrane stability of $15.27 \% \pm 8.53 \%$ at $0.4 \mathrm{mg} / \mathrm{mL}$ and maximum activity of $62.51 \%$ $\pm 10.27 \%$, at $1 \mathrm{mg} / \mathrm{mL}$.

Compound 2 also exerted minimum and maximum percentage stability activities of $12.89 \% \pm 3.61 \%$ and $75.63 \% \pm 8.40 \%$, at 0.2 and $0.6 \mathrm{mg} / \mathrm{mL}$ respectively. The response of the red blood cell was also monophasic and biphasic at all the tested concentrations (Table 5(c)).

At 0.4 and $0.6 \mathrm{mg} / \mathrm{mL}$ concentration compound 3 exerted minimal and maximal percentage stability activities of $8.13 \% \pm 0.25 \%$ and $67.70 \% \pm 0.78 \%$ respectively (Table $5(\mathrm{~d})$ ). The response of the red blood cell was also monophasic and biphasic at all the tested concentrations for this compound. For compound 4 the lowest percentage activity was $9.31 \% \pm 2.29 \%$ at 0.40 . On the other hand, the highest percentage activity was $66.67 \% \pm 0.78 \%$ at $1.00 \mathrm{mg} / \mathrm{mL}$ concentration (Table 5(e)).

Compound 5 gave membrane stability of $93.40 \% \pm 1.04 \%$ and $71.92 \% \pm 8.85 \%$ as maximum and minimum percentage activity respectively. The response of the red blood cells was also monophasic and biphasic to this compound (Table 5(f)). It is interesting to note that the ligand $\mathrm{L}$ and compounds 1-5 all elicited significantly better membrane stabilizing ability in relation with the standard drug (diclofenac).

The result obtained indicated that ligand $\mathrm{L}$ provided the highest protection against induced lyses of the tested cells (Table 5(a)). This therefore suggest that coordination, in this case, did not enhance the membrane stability activity of ligand L. Earlier workers have suggested that one of the possible modes of action of anti-inflammatory drugs involves their binding to the erythrocyte membranes with subsequent alteration of the surface charges of the cells [41] [66] [67]. A consequence of this is that they prevent physical interaction with aggregating agents. It is therefore, suggested that this may be the reason behind the better activity of ligand $\mathrm{L}$ in comparison to its coordination compound counterparts. Other researchers further suggested that anti-inflammatory drugs may promote 
Table 5. (a) Membrane stability activity for Ligand L; (b) Membrane stability activity for compound 1; (c) Membrane stability activity for compound 2; (d) Membrane stability activity for compound 3; (e) Membrane stability activity for compound 4; (f) Membrane stability activity for compound 5 .

(a)

\begin{tabular}{ccc}
\hline Concentration & \% Stability & SEM \\
\hline 0.2 & 91.3199 & 1.55351 \\
0.4 & 95.9752 & 1.11085 \\
0.6 & 70.2161 & 11.0807 \\
0.8 & 41.8702 & 1.68595 \\
1 & 38.166 & 0.27248 \\
\hline
\end{tabular}

(b)

\begin{tabular}{ccc}
\hline Concentration & \% Stability & SEM \\
\hline 0.2 & 38.8647 & 3.92197 \\
0.4 & 15.2745 & 8.53448 \\
0.6 & 15.7856 & 0.85955 \\
0.8 & 33.4467 & 0.75453 \\
1 & 62.5122 & 10.276 \\
\hline
\end{tabular}

(c)

\begin{tabular}{ccc}
\hline Concentration & \% Stability & SEM \\
\hline 0.2 & 75.6482 & 8.40456 \\
0.4 & 76.99 & 0.83649 \\
0.6 & 12.8954 & 3.6144 \\
0.8 & 33.7634 & 1.45265 \\
1 & 19.6234 & 3.02634 \\
\hline
\end{tabular}

(d)

\begin{tabular}{ccc}
\hline Concentration & \% Stability & SEM \\
\hline 0.2 & 66.3678 & 8.34449 \\
0.4 & 67.7096 & 0.7861 \\
0.6 & 8.13472 & 0.25595 \\
0.8 & 24.483 & 1.51365 \\
1 & 10.343 & 2.98993 \\
\hline
\end{tabular}

(e)

\begin{tabular}{ccc}
\hline Concentration & \% Stability & SEM \\
\hline 0.2 & 54.5145 & 0.46124 \\
0.4 & 66.6784 & 0.78081 \\
0.6 & 13.8832 & 5.68393 \\
0.8 & 23.4519 & 1.52054 \\
1 & 9.31179 & 2.98599 \\
\hline
\end{tabular}

(f)

\begin{tabular}{ccc}
\hline Concentration & \% Stability & SEM \\
\hline 0.2 & 81.23 & 0.862 \\
0.4 & 93.4017 & 1.04516 \\
0.6 & 71.9273 & 8.8526 \\
0.8 & 92.5036 & 1.7808 \\
1 & 89.8916 & 2.16915 \\
\hline
\end{tabular}


dispersal of like charges which are involved in the haemolysis of red blood cells, by mutual repulsion [41]. This may also be the case for ligand $\mathrm{L}$, which is purely organic in nature. Buttressing this fact are reports that allude to the fact that certain phenolic compounds exert profound stabilizing effect on lysosomal membrane both in vivo and in vitro [41] [66] [67]. In addition to this, some phenolic compounds have been reported to bind to cations and other macromolecules on the membrane, forming insoluble complexes thereby stabilizing erythrocyte membranes [41] [66] [67]. In this research, our investigation revealed that both ligand $\mathrm{L}$ and compounds 1-5 were able to prevent lysis of the tested erythrocyte membranes significantly. This therefore, suggests the potential of these compounds as good anti-inflammatory agents. The observed activity may be attributable in part to the phenolic substituent and the ability of these compounds to bind with ions and molecules on the erythrocyte membrane. The result obtained may therefore stand to further validate, the aforementioned mechanisms of activity.

\subsubsection{Protein Denaturation Activity}

The fact that denaturation of protein molecules is linked with inflammation process in conditions like arthritis is well documented in literature [15]. In fact, according to Gunathilake et al., 2018, one of the main mechanisms of action of non-steroidal anti-inflammatory drugs, NSAIDs, in the market, is the protection against protein denaturation [15]. The results obtained demonstrated that ligand $\mathrm{L}$ and compounds 1-5 can significantly and dose dependently protect against protein denaturation. Compound 2 exhibited a significantly higher $(p \leq 0.001)$ level of inhibition compared to other compounds studied with percentage activity of $63.38 \% \pm 0.001 \%$ at $1.00 \mathrm{mg} / \mathrm{mL}$ and $\mathrm{IC}_{50}$ of $0.47 \mathrm{~mol} / \mathrm{L}$ (Table 6 ). Whereas compound 5 showed the lowest inhibition levels with $42.08 \% \pm 0.001 \%$ also at $1.00 \mathrm{mg} / \mathrm{mL}$ with $\mathrm{IC}_{50} 1.41 \mathrm{~mol} / \mathrm{L}$. The order of the inhibition by the compounds is $\mathbf{2}>\mathbf{3}>\mathbf{1}>\mathrm{L}>\mathbf{4}>\mathbf{5}$. The result obtained from this investigation suggested good ability of the tested samples in small concentrations to protect against protein denaturation (Table 6). However, the standard drug, diclofenac, at all tested concentration, depicted significantly ( $p \leq 0.001)$ better anti-denaturation activity compared to all the synthesized compounds. The standard drug exhibited its highest activity at $70.04 \% \pm 0.001 \%$ at $10 \mu \mathrm{g} / \mathrm{mL}$ with $\mathrm{IC}_{50} 1.59 \mathrm{~mol} / \mathrm{L}$.

Table 6. Inhibition of protein denaturation activity.

\begin{tabular}{cccl}
\hline Compounds & IC $_{50}$ & SD & SEM \\
\hline $\mathbf{L}$ & 0.9207815 & 0.012531472 & 0.00886 \\
$\mathbf{1}$ & 0.7031428 & 0.020174767 & 0.01427 \\
$\mathbf{2}$ & 0.4788195 & 0.041849947 & 0.02959 \\
$\mathbf{3}$ & 0.5467983 & 0.013976678 & 0.00988 \\
$\mathbf{4}$ & 1.0127851 & 0.005460281 & 0.00386 \\
$\mathbf{5}$ & 1.4113157 & 0.055923536 & 0.03954
\end{tabular}


Inflammation is primarily a bodily response to injury, infection or destruction disturbed physiological functions, which entails various processes [15]. Previous researches suggested that most of the non-steroidal drugs act as an anti-inflammatory agent either by inhibiting hydrolytic enzymes, denaturation of proteins or by membrane stabilization process [15]. It may therefore be deduced from the results obtained that chemically and structurally the synthesized compounds are better suited as anti-inflammatory agents by preventing or retarding the rupturing of lysosomal membrane. One of the fundamental goals of this research was to enable us to streamline and put in perspective the biological activity of the synthesized compounds. This is geared toward tailoring the anti-inflammatory activity. In this respect, further definitive studies are necessary, this with further structural analysis for the compounds are currently underway.

\section{Conclusion}

The present work demonstrated that the diazo-coupling of 2-amino-4,5-dimethylthiazole with 5-methyl-2-(propan-2-yl)phenol affords a thiazoylazo dye, ligand $\mathrm{L}$. Coordination of $\mathrm{Cu}(\mathrm{II}), \mathrm{Mn}(\mathrm{II})$ and $\mathrm{Ni}(\mathrm{II})$ metal ion with this ligand gave octahedral geometry. The $\mathrm{Zn}$ (II) and $\mathrm{Co}(\mathrm{II})$ complexes assumed square planar geometry. The study further investigated the enzyme inhibitory and anti-inflammatory activities of the synthesized compounds. It was concluded that the primary mode of anti-inflammatory activity of the compounds was by the prevention of lysosomal membrane from lyses.

\section{Conflicts of Interest}

The author declares no conflicts of interest regarding the publication of this paper.

\section{References}

[1] Ramsay, R.R. and Tipton, K. (2017) Assessment of Enzyme Inhibition: A Review with Examples from the Development of Monoamine Oxidase and Cholinesterase Inhibitory Drugs. Molecules, 22, Article No. 1192. https://doi.org/10.3390/molecules22071192

[2] Balbaa, M. and El Ashry, E. (2012) Enzyme Inhibitors as Therapeutic Tools. Biochemistry \& Physiology, 1, Article No. 103. https://doi.org/10.4172/2168-9652.1000103

[3] Copeland, R.A., Harpel, M.R. and Tummino, P.J. (2007) Targeting Enzyme Inhibitors in Drug Discovery. Expert Opinion on Theurapeutic Targets, 11, 967-978. https://doi.org/10.1517/14728222.11.7.967

[4] Bjelaković, G., Stojanović, I., Bjelaković, B.J., Pavlović, D. and Daković-Milić, K.A. (2002) Competitive Inhibitors of Enzymes and Their Therapeutic Application. Medicine and Biology, 9, 201-206.

[5] Ouertani, A., Neifar, M., Ouertani, R., Masmoudi, A.S., Mosbah, A. and Cherif, A. (2019) Effectiveness of Enzyme Inhibitors in Biomedicine and Pharmacotherapy. Advances in Tissue Engineering and Regenerative Medicine, 5, 85-90.

[6] Habala, L., Devinsky, F. and Egger, A.E. (2018) REVIEW: Metal Complex as Urease 
Inhibitors. Journal of Coordination Chemistry, 71, 907-940. https://doi.org/10.1080/00958972.2018.1458228

[7] Ye, R., Tan, C., Chen, B., Li, R. and Mao, Z. (2020) Zinc-Containing Metalloenzymes: Inhibition by Metal-Based Anticancer Agents. Frontiers in Chemistry, 8, Article No. 402. https://doi.org/10.3389/fchem.2020.00402

[8] Che, C.-M. and Siu, F.-M. (2010) Metal Complexes in Medicine with a Focus on Enzyme Inhibition. Current Opinion in Chemical Biology, 14, 255-261. https://doi.org/10.1016/j.cbpa.2009.11.015

[9] Kilpin, K.J. and Dyson, P.J. (2013) Enzyme Inhibition by Metal Complexes: Concepts, Strategies and Applications. Chemical Science, 4, 1410-1419. https://doi.org/10.1039/C3SC22349C

[10] Louie, A.Y., Meade, T.J. and Lippard, S.J. (1999) Metal Complexes as Enzyme Inhibitors. Chemical Reviews, 99, 2711-2734. https://doi.org/10.1021/cr9804285

[11] Meggers, E. (2009) Targeting Proteins with Metal Complexes Chemical Communication, 7, 1001-1010. https://doi.org/10.1039/B813568A

[12] Jesmin, M., Islam, M.K. and Ali, S.M.M. (2014) Analgesic and Anti-Inflammatory Activities of Some Transition Metal Schiff Base Complexes. International Letters of Chemistry, Physics and Astronomy, 27, 64-72. https://doi.org/10.18052/www.scipress.com/ILCPA.27.64

[13] Chowdhury, A., Azam, S., Jainul, M., Faruq, K. and Islam, A. (2014) Antibacterial Activities and In Vitro Anti-Inflammatory (Membrane Stability) Properties of Methanolic Extracts of Gardenia Coronaria Leaves. International Journal of Microbiology, 2014, Article ID: 410935. https://doi.org/10.1155/2014/410935

[14] Eggleton, P. (2001) Hypersensitivity: Immune Complex Mediated (Type III). In:, Encyclopedia of Life Sciences, John Wiley \& Sons, Ltd., Hoboken, 1-9. https://doi.org/10.1038/npg.els.0001138

[15] Gunathilake, K.D., Ranaweera, K.K. and Rupasinghe, H.P. (2018) In Vitro Anti-Inflammatory Properties of Selected Green Leafy Vegetables. Biomedicines, 6, Article No. 107. https://doi.org/10.3390/biomedicines6040107

[16] Mohamed, T.K., Azeem, A.K., Dilip, C., Sankar, C., Prasanth, N.V. and Duraisami, R. (2011) Anti-Inflammatory Activity of the Leaf Extacts of Gendarussa Vulgaris Nees. Asian Pacific Journal of Tropical Biomedicine, 1, 147-149. https://doi.org/10.1016/S2221-1691(11)60014-2

[17] Sarveswaran, R., Jayasuriya, W.J.A. and Suresh, T.S. (2017) In Vitro Assays to Investigate the Anti-Inflammatory Activity of Herbal Extracts: A Review. World Journal of Pharmaceutical Research, 6, 131-141.

[18] Shukla, S. and Mishra, A.P. (2014) Metal Complexes Used as Anti-Inflammatory Agents: Synthesis, Characterization and Anti-Inflammatory Action VO(II)-Complexes. Arabian Journal of Chemistry, 12, 1715-1721. https://doi.org/10.1016/j.arabjc.2014.08.020

[19] Harizi, H. and Gualde, N. (2004) 5-Lipoxygenase Pathway, Dendritic Cells, and Adaptive Immunity. Journal of Biomedicine and Biotechnology, 99-105. https://doi.org/10.1155/S1110724304310041

[20] Nguemnang, S.F., Tsafack, E.G., Mbiantcha, M., Gilbert, A., Atsamo, A.D., et al. (2019) In Vitro Anti-Inflammatory and In Vivo Antiarthritic Activities of Aqueous and Ethanolic Extracts of Dissotis Thollonii Cogn. (Melastomataceae) in Rats. Evidence-Based Complementary and Alternative Medicine, 2019, Article ID: 3612481. https://doi.org/10.1155/2019/3612481

[21] Kumar, V., Abbas, A.K., Fausto, N. (2004) Robbins and Cotran Pathological Basis of 
Disease. 7th Edition, Saunders, Philadelphia, 47-86.

[22] Hasan, A.U.H. (2019) Evaluation of In Vitro and In Vivo Therapeutic Efficacy of Ribes Alpestre Decne in Rheumatoid Arthritis. Brazilian Journal of Pharmaceutical Sciences, 55, Article No. e17832. https://doi.org/10.1590/s2175-97902019000217832

[23] Adu, J.K., Amengor, C.D., Ibrahim, N.M., Amaning-Danquah, C., Ansah, C.O., Gbadago, D.D., et al. (2020) Synthesis and In-Vitro Antimicrobial and Antihelminthic Evaluation of Naphtholic and Phenolic Azo Dyes. Journal of Tropical Medicine, 2020, Article ID: 4850492. https://doi.org/10.1155/2020/4850492

[24] Gaffer, H.E. (2019) Antimicriobial Sulphonamide Azo Dyes. Coloration Technology, 135, 484-500. https://doi.org/10.1111/cote.12437

[25] Ali, Y., Hamid, S.A. and Rashid, U. (2018) Biomedical Applications of Aromatic Azo Compounds. Mini-Reviews in Medicinal Chemistry, 18, 1548-1558. https://doi.org/10.2174/1389557518666180524113111

[26] Akram, D., Elhaty, I.A. and AlNeyadi, S.S. (2020) Synthesis and Antibacterial Activity of Rhodanine-Based Azo Dyes and Their Use as Spectrophotometric Chemosensor for $\mathrm{Fe}^{3+}$ Ions. Chemosensors, 8, Article No. 16. https://doi.org/10.3390/chemosensors8010016

[27] Gouda, M.A., Eldien, H.F., Girges, H.H. and Bergot, M.A. (2012) Synthesis and Antitumor Evaluation of Thiophene Based Azo Dyes Incorporating Pyrazolone Moiety. Journal of Saudi Chemical Society, 20, 151-157.

https://doi.org/10.1016/j.jscs.2012.06.004

[28] Mallikarjuna, N.M. and Keshavayya, J. (2018) Synthesis, Spectroscopic Characterization and Pharmacological Studies on Novel Sulfamethaxazole Based Azo Dyes. Journal of King Saud University, 32, 251-259.

[29] Mohamed, F.A., Abd El-Megied, S.A., Bashandy, M.S. and Ibrahim, H.M. (2018) Synthesis, Application and Antibacterial Activity of New Reactive Dyes Based on Thiazole Moiety. Pigments and Resins Technology, 47, 246-254. https://doi.org/10.1108/PRT-12-2016-0117

[30] Adejumo, T.T., Tzouras, N.V., Zorba, L.P., Radanović, D., Pevec, A., Grubišić S., et al. (2020) Synthesis, Characterization, Catalytic Activity, and DFT Calculations of Zn(II) Hydrazone Complexes Molecules, 25, Article No. 4043. https://doi.org/10.3390/molecules25184043

[31] Yurtta, L.G., Özkay, Y., Gençer, H.K. and Acar, U. (2015) Synthesis of Some New Thiazole Derivatives and Their Biological Activity Evaluation. Journal of Chemistry, 2015, Article ID: 464379. https://doi.org/10.1155/2015/464379

[32] Fadda, A.A., El Salam, M.A., Tawfik, E.H., Anwar, E.M. and Etman, H.A. (2017) Synthesis and Insecticidal Assessment of Some Innovative Heterocycles Incorporating a Thiadiazole Moiety against the Cotton Leafworm, Spodoptera Littoralis. RSC Advances, 7, 39773-39785. https://doi.org/10.1039/C7RA06087D

[33] Al-Adilee, K.J. and Adnan, S. (2017) Synthesis and Spectral Properties Studies of Novel Heterocyclic Mono Azo Dye Derived from Thiazole and Pyridine with Some Transition Complexes. Oriental Journal of Chemistry, 33, 1815-1827. https://doi.org/10.13005/ojc/330426

[34] Kumawat, M.K. (2018) Thiazole Cointaining Heterocycles with Antimalarial Activity. Current Drug Discovery Technology, 15, 196-200. https://doi.org/10.2174/1570163814666170725114159

[35] Noble, S. and Blfour, J.A. (1996) Meloxicam. Drugs, 51, 424-430. https://doi.org/10.2165/00003495-199651030-00007

[36] Aiyelabola, T., Akinkunmi, E., Obuotor, E., Olawuni, I., Isabirye, D. and Jordaan, J. (2017) Synthesis Characterization and Biological Activities of Coordination Com- 
pounds of 4-Hydroxy-3-Nitro-2H-Chromen-2-One and Its Aminoethanoic Acid and Pyrrolidine-2-Carboxylic Acid Mixed Ligand Complexes. Bioinorganic Chemistry and Applications, 2017, Article ID: 6426747.

https://doi.org/10.1155/2017/6426747

[37] Chohan, Z.H., Arif, M., Akhtar, M.A. and Supurean, C.T. (2006) Metal-Based Antibacterial and Antifungal Agents: Synthesis, Characterization and in Vitro Biological Evaluation of $\mathrm{Co}(\mathrm{II}), \mathrm{Cu}(\mathrm{II}), \mathrm{Ni}(\mathrm{II})$, and $\mathrm{Zn}(\mathrm{II})$ Complexes with Amino Acid-Derived Compounds. Bioinorganic Chemistry and Application, 2006, Article ID: 831837. https://doi.org/10.1155/BCA/2006/83131

[38] Chang, E., Simmers, C. and Knight, D.A. (2010) Cobalt Complexes as Antiviral and Antibacterial Agents. Pharmaceuticals, 3, 1711-1728. https://doi.org/10.3390/ph3061711

[39] Sakurai, H., Yoshikawa, Y., Kawabe, K. and Yasui, H. (2002) Antidiabetic Vanadium(IV) and Zinc(II) Complexes. Coordination Chemistry Reviews, 226, 187-198. https://doi.org/10.1016/S0010-8545(01)00447-7

[40] Nguyen, M.T., Awale, S., Tezuka, Y., Ueda, J., Ueda, J., Le Tran, Q. and Kadota, S. (2006) Xanthine Oxidase Inhibitors from the Flowers of Chrysanthemum Sinense. Planta Medica, 72, 46-51. https://doi.org/10.1055/s-2005-873181

[41] Oyedapo, O.O., Akinpelu, B.A., Akinwunmi, K.F., Adeyinka, M.O. and Sipeolu, F.O. (2010) Red Blood Cell Membrane Stabilizing Potentials of Extracts of Lantana Camara and Its Fractions. International Journal of Plant Physiology and Biochemistry, 2, 46-51.

[42] Gambhire, M., Juvekar, A. and Wankhede, S. (2009) Evaluation of the Anti-Inflammatory Activity of Methanol Extract of Barleria Cristata Leaves by In Vivo and In Vitro Methods. International Journal of Pharmacology, 7, 1-6.

[43] Nakamoto, K. (2009) Infrared and Raman Spectroscopy of Inorganic and Coordination Compounds: Applications in Coordination, Organometallics and Bioinorganic Chemistry. 6th Edition, John Wiley and Sons, New York, 67-69.

[44] Pavia, G., Lampman, G. and Kriz, G. (2001) Introduction to Spectroscopy: A Guide for Students of Organic Chemistry. 3rd Edition, Brooks and Cole, Pacific Grove, 22-368.

[45] Kemp, W. (1999) Organic Spectroscopy. 3rd Edition, Macmillan, Hong Kong, 19-98.

[46] Osowole, A.A., Kolawole, O.E. and Fagade, S. (2008) Synthesis Physicochemical and Biological Properties of Nickel(II), Copper(II) and Zinc(II) Complexes of an Unsymmetrical Tertradentate Schiff Base and Adducts with 2,2'-dipyridine and 1,10-phenantroline. Journal of Coordination Chemistry, 61, 1046-1055. https://doi.org/10.1080/00958970701482446

[47] Osowole, A. (2011) Synthesis, Characterization and Magnetic and Thermal Studies on Some Metal(II) Thiophenyl Schiff Base Complexes. International Journal of Inorganic Chemistry, 2011, Article ID: 650186. https://doi.org/10.1155/2011/650186

[48] Youssef, N.S. and Hegab, K.H. (2005) Synthesis and Characterization of Some Transition Metal Complexes of Thiosemicarbazones Derived from 2-Acetylpyrrole and 2-Acetylfuran. Synthesis and Reactivity in Inorganic Organic and Nano Metal Chemistry, 35, 391-399. https://doi.org/10.1081/SIM-200059215

[49] Aiyelabola, T.O., Akinkunmi, E., Ojo, I., Obuotor, E., Adebajo, C. and Isabirye, D. (2017) Syntheses, Characterization, Resolution and Biological Studies of Coordination Compounds of Aspartic Acid and Glycine. Bioinorganic Chemistry and Applications, 2017, Article ID: 2956145. https://doi.org/10.1155/2017/2956145

[50] Miessler, G.L. and Tarr, D.A. (1999) Inorganic Chemistry. Pearson Prentice Hall, New York, 315-316. 
[51] Greenwood, N.N. and Earnshaw, A. (1997) Chemistry of the Elements. 2nd Edition, Butterworth-Heinemann, Oxford, Hong Kong, 1060-1090, 1290-1326.

[52] Raman, N., Pothiraj, K. and Baskaran, T. (2011) Synthesis, Characterization and DNA Damaging of Bivalent Metal Complexes Incorporating Dinitrogen-Dioxygen Ligand as Potential Biocidal Agent. Journal of Coordination Chemistry, 64, 4286-4330. https://doi.org/10.1080/00958972.2011.638979

[53] Anitha, C., Sheela, C.D., Tharmaraj, P. and Shanmugakala, R. (2013) Studies on Synthesis and Spectral Characterization of Some Transition Metal Complexes of Azo-Azomethine Derivative of Diaminomaleonitrile. International Journal of Inorganic Chemistry, 2013, Article ID: 436275. https://doi.org/10.1155/2013/436275

[54] Aiyelabola, T.O., Jordaan, J., Otto, D. and Akinkunmi, E. (2021) Synthesis Characterization and Biological Activities of an Enamine Derivative and Its Coordination Compounds Advances in Biological Chemistry, 10, 172-189.

https://doi.org/10.4236/abc.2020.106013

[55] Borges, F., Fernandes, E. and Roleira, F. (2002) Progress towards the Discovery of Xanthine Oxidase Inhibitors. Current Medicinal Chemistry, 9, 195-217. https://doi.org/10.2174/0929867023371229

[56] Osman, N., Sidik, N.J., Awal, A., Adam, N.A. and Rezali. N.I. (2016) In Vitro Xanthine Oxidase and Albumin Denaturation Inhibition Assay of Barringtonia Racemosa L. and Total Phenolic Content Analysis for Potential Anti-Inflammatory Use in Gouty Arthritis. Journal of Intercultural Ethnopharmacology, 5, 343-349. https://doi.org/10.5455/jice.20160731025522

[57] Virsaladze, D.K., Tetradze, L.O., Dzhavashvili, L.V., Esaliia, N.G. and Tananashvili, D.E. (2007) Levels of Uric Acid in Serum in Patients with Metabolic Syndrome. Georgian Medical News, 146, 35-37.

[58] Aiyelabola, T.O., Akinkunmi, E.O. and Osungunna, O. (2021) Syntheses, Characterization and Biological Activity of Coordination Compounds of Propanedioic Acid and its Mixed Ligand Complexes with N,N'-Dihydroxy-2,3-Butanediimine. Asian Journal of Chemistry, 33, 1911-1918. https://doi.org/10.14233/ajchem.2021.23309

[59] Sweeney, A.P., Wyllie, S.G., Halliker, R.A. and Markham, J.L. (2001) Xanthineoxidase Inhibitory Activity of Selected Australian Native Plants. Journal of Ethnopharmacology, 75, 273-277. https://doi.org/10.1016/S0378-8741(01)00176-3

[60] Schneider, I. and Bucar, F. (2005) Lipoxygenase Inhibitors from Natural Plant Sources. Part 1: Medicinal Plants with Inhibitory Activity on Arachidonate 5-Lipoxygenase and 5-Lipoxygenase[sol]cyclooxygenase. Phytotherapy Research, 19, 81-102. https://doi.org/10.1002/ptr.1603

[61] Schneider, I. and Bucar, F. (2005) Lipoxygenase Inhibitors from Natural Plant Sources. Part 2: Medicinal Plants with Inhibitory Activity on Arachidonate 12-Lipoxygenase, 15-Lipoxygenase and Leukotriene Receptor Antagonists. Phytotherapy Research, 19, 263-272. https://doi.org/10.1002/ptr.1604

[62] Zeraik, M.L., Pauli, I., Dutra, L.A., Cruz, R.S., Valli, M., et al. (2021) Identification of a Prenyl Chalcone as a Competitive Lipoxygenase Inhibitor: Screening, Biochemical Evaluation and Molecular Modeling Studies. Molecules, 26, Article No. 2205. https://doi.org/10.3390/molecules26082205

[63] Bruno, F., Spaziano, G., Liparulo, A., Roviezzo, F., Nabavi, S.M., et al. (2018) Recent Advances in the Search for Novel 5-Lipoxygenase Inhibitors for the Treatment of Asthma. European Journal of Medicinal Chemistry, 153, 65-67. https://doi.org/10.1016/j.ejmech.2017.10.020

[64] Okoli, C.O., Akah, P.A., Onuoha, N.J., Okoye, T.C., Nwoye, A.C. and Nworu, C.S. (2008) Acanthus montanus. An Experimental Evaluation of the Antimicrobial, An- 
ti-Inflammatory and Immunological Properties of a Traditional Remedy for Furuncles. BMC Complementary Alternative Medicine, 8, Article No. 27.

https://doi.org/10.1186/1472-6882-8-27

[65] Umapathy, E., Ndebia, E.J., Meeme, A., Adam, B., Menziwa, P., Nkeh-Chungag, B.N. and Iputo, J.E. (2010) An Experimental Evaluation of Albuca setosa Aqueous Extract on Membrane Stabilization, Protein Denaturation and White Blood Cell Migration during Acute Inflammation. Journal of Medicinal Plants Research, 4, 789-795.

[66] Middleton, J.E. (1996) Biological Properties of Plant Flavonoids: An Overview. International Journal of Pharmacognosy, 34, 344-348.

https://doi.org/10.1076/phbi.34.5.344.13245

[67] El-Shabrany, O.A., El-Gindi, O.D., Melek, F.R., Abdel-Khalk, S.M. and Haggig, M.M. (1997) Biological Properties of Saponin Mixtures of Fagonia Cretica and Fagonia Mollis. Fitoterapia, 68, 219-222. 